\title{
19
}

\section{Visualising the Prophet - Rhetorical and Graphic Aspects of Three Ottoman-Turkish Poems}

\author{
Süleymān Çelebi’s Vesīlet en-Necāt, Yazıcıoğlı's Risāle-i Muḥammedīye, and \\ Hākāānòs Hilye
}

\section{Tobias Heinzelmann}

Narrative and panegyric poems about the Prophet Muhammad were among the most widely read texts in the Ottoman Empire. They made the Prophet accessible to a broad readership; they were recited during rites; and the acts of copying them with one's own hand, reading them, and presenting them as endowments promised reward on the day of judgement. There also was a strong visual aspect to the production and usage of these manuscripts: the beauty of the Prophet, the beauty of the (spoken) word, and the beauty of the handwriting were interrelated. Much can therefore be learned about the image of the Prophet Muhammad in Ottoman society, and specifically in Ottoman book culture, by analysing this interrelation.

In my study I focus on three poems, which are preserved in large numbers in manuscript collections all over the world, and which were published in several printed editions - Süleymān Çelebi's Vesīlet en-Necāt (812/1409), Yazıcıŏ̆lı Muhammed's Muhammedīye (853/1449), and Hāḳānī's Hilye (1007/1598-9). These have several features in common: their topic (the biography and/or the physiognomy of Muhammad); their form (poetry); the fact that the texts are transmitted with the signature of their author; and a precise date. However, the authors employed very different strategies to visualise the Prophet, and so did the copyists, calligraphers, and illustrators.

The three texts are analysed successively. Each section begins with a short survey of the intention of the authors as described in prefaces or colophons, and, if relevant, later biographical and hagiographical texts. Then the structure of the texts and narrative, along with their poetical and rhetorical characteristics, will be described, and, in a concluding step, the interrelation with graphic aspects of selected manuscripts and printed copies is explored. 
Süleymān Çelebi presents his Vesīlet en-Necāt (Means to Salvation), which is commonly known as Mevlid (The Prophet's Birthday), to his readers with a standard set of information about himself - his name (Süleymān), the date (812/1409), and the location (Bursa) where he finished the text. His remarks about his motivation and intention are also quite commonplace - according to the introduction he wanted to transmit knowledge about the Prophet Muhammad, to seek God's reward, and to request intercession from his readers on his behalf. ${ }^{1}$

Already in the sixteenth and seventeenth centuries the authors of biographical encyclopaedias had some difficulties identifying Süleymān Çelebi. ${ }^{2}$ They agreed to locate him in proximity to the Sultan's palace. Lațîfi's Tezzkiret eş-Şu'arā (953/1546) asserts that he was the son of 'Ivaż Paşa, a grand vizier of Murād II (reg 824-855/1421-1451). According to Muștafā 'Ālī's Künh el-Ahbār (ca. 1008/16oo) he himself was member of the council of Sultan Bāyezìd I and, after the Sultan's death, imam of the Great Mosque in Bursa. ${ }^{3}$ It is also in Lațîfi's Težkiret eş-Şu'arā where we find a detailed narrative about the occasion which led the author to write his poem: It was a conflict over the hierarchy of prophets and of Muhammad's distinguished and outstanding position among them. ${ }^{4}$ According to the narrative, a preacher in Bursa had claimed that all prophets were equal before God and referred to Q 2:285. Therefore, Süleymān Çelebi decided to write a poem about the outstanding rank of Muhammad.

Süleymān Çelebi's text has a special focus on the creation and birth of Muhammad - but is not restricted to these themes, as the commonly known title Mevlid might suggest. It contains narrative and panegyric passages and is written in a plain Old-Ottoman-Turkish language. The poetic form of Süleymān Çelebi's Vesillet en-Necāt is the mesnevī. The transmitted text is characterised by a high degree of variance: there exist versions of $150-200$ verses and others of 1200-1300 verses. ${ }^{5}$ In 1306/1888 a certain Riżā Efendi published a collated edition, which is the first claiming to reconstruct the "original version". This

Ateş, Süleymān Çelebi, 95 and 143-7.

2 Heinzelmann, Populäre, $49 \mathrm{ff}$.

3 Muștafā 'Ālī, Künh el-Ahbar, 5, 115-6.

4 Lațîî, Tezzkiret eş-Şu'arā, 133 ff.

5 Ateş, Süleyman Çelebi, 61. Pekolcay also compiled her edition as her PhD-thesis in the 195os. However, it was first published only in 1980. Pekolcay's edition again focusses on a reconstruction of the "original text", but does not give an adequate impression of its variance. 
edition was reprinted several times. ${ }^{6}$ But it is only the edition of Ahmed Ateş in 1954 that succeeds in giving an impression of the broad variance of the text.

The chapter about Muhammad's birth begins with an easily intelligible narrative: ${ }^{7}$
Āmine hatun Muhammed annesi
Ol sedefden țoğdı ol bir dānesi
Hem Muhammed gelmesi oldı yakīn
Çoḳ 'alāmetler bilürdi gelmedin
Çünki 'Abdullāhdan oldı ḥāmile
Vakt èrişdi hafta ve eyyāmile
Ol-gècesi kim țog்dı ol ḩayrü l-beşer
Annesi anda neler gördi neler
On ikincisi Rebīü l-Evvelüñ
Ol düşenbe gècesi idi bilüñ

In the translation of Elias John Wilkinson Gibb this reads as follows:"

Lady Ámine, Muhammed's mother she, (From this Shell it was yon Pearl did come to be.)

When Muhammed's time to come was near at hand,

Ere he came were many signs seen through the land.

Now by 'Abd-ulláh his sire had she conceived,

And the passing weeks and days the term achieved.

In the night wheron was born that Best of $\mathrm{Men}^{9}$

Many a marvel passed before his mother's ken.

On the twelfth 'twas of the First Rebí' it fell,

On a Monday night it tided, wot ye well!

Süleymān Çelebi's text does not particularly emphasise the physiognomy of the Prophet. References are, however, detectable in a few isolated cases. In the chapter about the miracles Süleymān Çelebi explains that Muhammad

6 Heinzelmann, Populäre, 127-8. According to Özege, Eski Harflerle, 2:1131-2, Süleymān Çelebi's Vesïlet en-Necāt was printed 26 times. Riżā Efendi's edition is dated 18 Muharrem 1306.

7 The transcription follows the Turkish text in Gibb's Ottoman Poetry, 6:22; cf. Riżā Efendi's edition, 1306, 7, Ateş, Süleymān Çelebi, 103-4, and Pekolcay, Mevlid, 76.

8 Gibb, Ottoman Poetry, 1, 243.

9 Footnote by Gibb, Ottoman Poetry, 1, 243: "Khayr-ul-Besher or Khayr-ul-Enám, i.e. 'Best of Mankind' is a frequent title of Muhammed." 
did not cast a shadow, since his body was made of pure light. In Süleymān Çelebi's Vesillet en-Necāt this statement is important for his argument for why Muhammad differs from the other prophets:10

Mu'cizātın diñleñüz şevk ile hōōş Gerçi cümle nūr idi ol pāk-i zeāt Ḥaḳ anı ayruḳ nebīye vẻrmedi Evvelā ol kim mübārek cisminüñ Nūr idi başdan ayag̉a göğdesi

Translation:

Listen with pure desire about his miracles

His pure existence was all of light

Which God didn't give the other prophets

First of all, his blessed body

His body was of light from top to toe
Tā ki 'aḳl-ü cān ḳ̂la cūş-u hưưuş Illlā her 'użvında vardı mu'cizāt Hīç biri ol èrdügine èrmedi Gölgesi düşmezdi yẻre resminüñ Bu 'ayāndur nūruñ olmaz gölgesi

So that your mind and soul will burn and flame

In all his limbs a miracle could be found

Which none of them had archived like him

Didn't cast a shadow on the ground

It's obvious, light has no shadow of the Manuscript

The layout and graphic characteristics of manuscripts and printed issues of Süleymān Çelebi's Vesilet en-necāt seem quite common at first sight. They follow classic, basic strategies to communicate the poetic form and rhetorical devices of the text. Copyists and printers neither illustrated it nor developed sophisticated calligraphic forms for it. The Vesilet en-necāt therefore contrasts with the manuscripts and prints of the two following texts - Yazıcığlı's Muhammedīye and Huākānī's Hilye. However, a closer look can help to decode the graphic strategies.

10 Ateş, Süleyman Çelebi, 113; Pekolcay, Mevlid, 100 . 
One of the general characteristics of the layout in Ottoman manuscripts and prints is that poems are organised in two "pseudo-columns" for the two semiverses $(m i s ̧ r a \overline{)})$. In contrast to usual columns (true columns) the two semiverses are read line for line across the columns. ${ }^{11}$ There are rare cases where this classic layout is changed to "true columns", with the semi-verses arranged one below the other, or a three-column scheme, where every second verse is divided by a line break, because one line contains three semi-verses. ${ }^{12}$ Two such cases are documented for Yazıcıoğlı's Muhammedīye and Huākānī's Hilye, but not for Süleymān Çelebi's Vesilet en-necāt. This, however - considering the rarity - does not mean that such Vesillet-manuscripts do not exist. But it is still one more indication of a rather frugal layout and illumination for this text. In both cases - "true columns" and a three-column scheme - the poetic form is disguised by the layout, for which a reason is not easily found. Maybe the copyist or editor wanted to attract the readers' attention and encourage him to engage via language and poetic form with the content of the text. ${ }^{13}$

Two aspects of the reproductions of Süleymān Çelebi's Vesilet en-necāt demonstrate the desire for an authentic text transmission, as well as the copyist's respect for author and text, namely the vowel signs and the aesthetic of the handwritten text. Manuscripts and prints of Süleymān Çelebi's poem are fully vocalised, which should be seen far more as a graphic marker than as an aid to decipher and understand it. Even if the vowel signs still had an important function in Old-Ottoman-Turkish orthography, due to a frequent defective writing of vowels, these were no longer necessary after the transition from a phonological to a morphological orthography of the suffixes, and there remained no option for a reasonable vocalisation of a text written in New-Ottoman-Turkish orthography. ${ }^{14}$ The fully vocalised text was - consciously or not - chosen as a marker, which reminded the readers of the most familiar model, the Qur'ān,

11 Daub, Formen und Funktionen, 49, Gacek, Arabic Manuscripts, 146f. and 177ff., Deroche, Islamic Codicology, 173 .

12 Daub, Formen, 103 and 113. Cf. Hilye-i Hākāañ, printing shop of Mahmud Beg, Istanbul 1307/1309/1891, 5o pages. In the same year an official printing shop (Maṭba'a-yi ‘Āmire?) edited the Hilye-i Hākānī with traditional layout (44 pages). For a Muhammedīyemanuscript in three columns cf. Millet Kütüphanesi, Istanbul, Ali Emiri Manzum 876/1, copied by Muhammed el-Ḥalīm b. Yahyā el-Üsküdārī, 1125/1713.

13 Cf. in this context the hātime in Maḥmud Beg's edition of the Hilye-i Hāḳāni from 1307/1309/1891, in which the readers are encouraged by the editor to recite the text aloud like the evrād - i.e. verses from the Qurān used for daily prayer and devotions. 
in which - in contrast to Ottoman-Turkish writings - the vowel signs are an essential aid to read and understand the text.

Most prints of Süleymān Çelebi's poem used lithography, which enabled the reproduction of a handwritten manuscript and facilitated the addition of vowel signs. However, it is significant that even prints with movable type were fully vocalised - and in this case, that made the printing process more complicated. But we also have evidence that it was not only technical or economic considerations which made lithography - and in the twentieth century also facsimile prints - the preferred printing technique. The notion of proper respect for the author, for the text, and thereby the religious content, viz. the Prophet Muhammad, was also an important factor. ${ }^{15}$ Also relevant is the blessing conferred by the process of copying with one's own hand. That concerns not only calligraphic copies in a narrow sense (i.e. copies in the classical ductus nesih, sülüs, or talïk), but handwritten copies in general.

Regarding the reproduction of handwritten copies, three printed editions of Süleymān Çelebi's Vesilet en-necāt from the twentieth and twenty-first centuries are revealing. Ahmed Ateş edited the text in 1954 in Latin characters, but he included a black and white facsimile of his codex optimus, sK Fatih 5430/1, which dates from $967 / 1560$. In this reproduction the margins outside the frame are cut off, which shows that the focus lies more on the philological aspects of the text than on its graphic and material appearance. In 1980, Pekolcay's edition - in Latin characters - included also a black and white reproduction in Arabic characters of a contemporary Turkish calligrapher (Turan Sevgili), who "modernised" Ottoman-Turkish orthography. In this edition, the handwritten copy in Arabic characters is rather meant to strengthen the attachment to the religious content of the poem. ${ }^{16}$ In 2008 , the publishing house of the Directorate of Religious Affairs printed a facsimile of a manuscript of Süleymān Çelebi's Vesīlet en-necāt, which was copied by the famous calligrapher Aḥmed Kāmil [Akdik] in 1349/1931 - two years after the introduction of Latin characters in Turkey. The copy was commissioned by Emīre Zibā [Tugay], daughter of field marshal Ḥasan Paşa. The text is based on Riżā Efendi's edition, and the manuscript has been masterfully written in nesih and richly illuminated. While it documents Emīre Zibā's esteem for Aḥmed Kāmil's calligraphic art, the choice of the Vesilet en-necāt is also telling: it is an indication for her respect for this text, its author and the topic - the Prophet Muhammad. In the reproduction

15 These factors for the choice of printing techniques in the nineteenth and twentieth centuries will be studied in an ongoing research project.

16 Pekolcay, Mevlid, 177, gives the names of the calligrapher (Turan Sevgili), the calligrapher of the front page (Hüsrev Subaşı), and the illuminator (Sadi Kucur). 


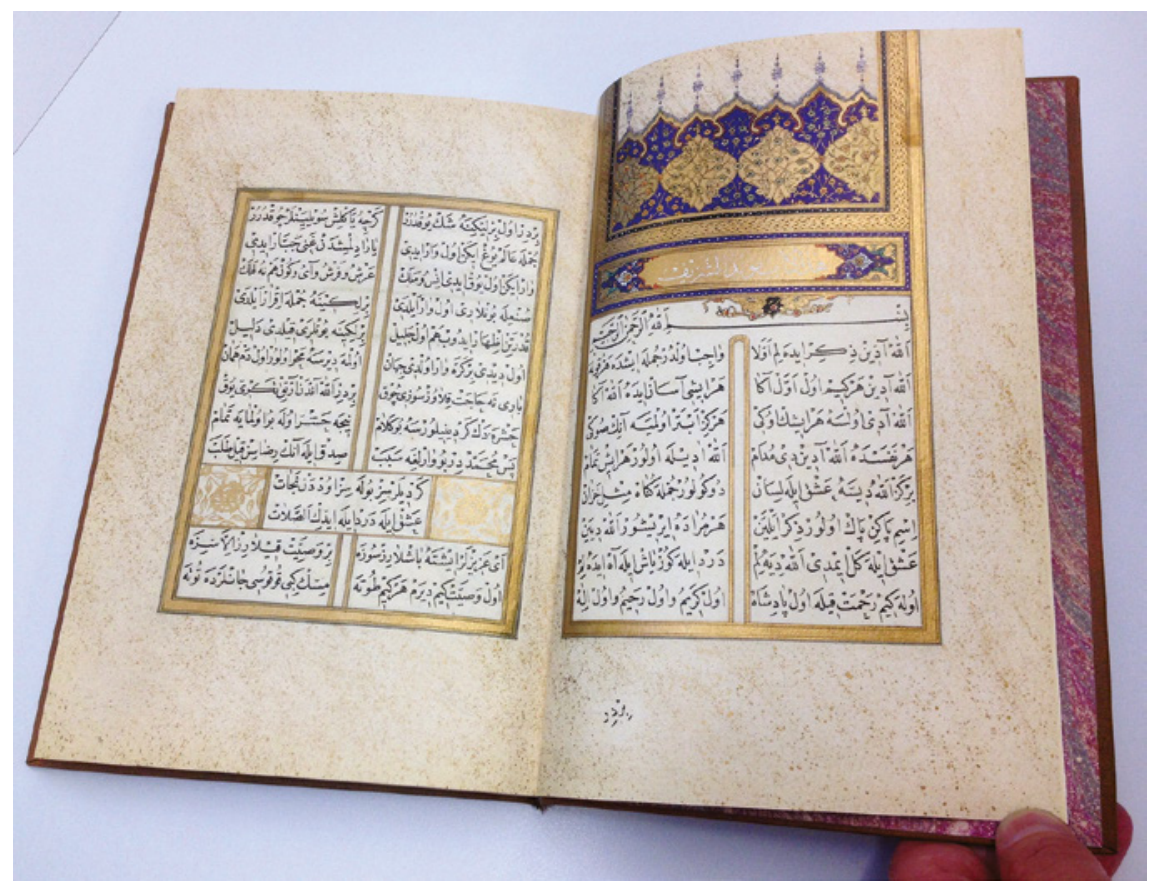

FIGURE 19.1 Recent Facsimile Edition of a Mevlid-manuscript, copied by the famous calligrapher Ahmed Kamil Akdik in 1931, Vesiletün-Necat, Diyanet İşleri Başkanlığı, Ankara 2008

of 2008, the process of text transmission receives an additional layer - introductory chapters about author, text, calligrapher, illuminator and purchaser locate Süleymān Çelebi's poem and Aḥmed Kāmil's copy in the context of an Ottoman book culture in the early Turkish Republic.

Yazıcıoğlı Muhammed, the author of the Risāle-iMuhammedìye (Muhammadan Treatise), which is commonly known as Muhammedīye, gives very detailed information about himself and his work in his introduction and colophon. ${ }^{17}$ He wrote the poem in Gelibolu (Gallipoli) and finished it 853/1449. According to the introduction, he was asked by his contemporaries to write a reliable book on the biography of the Prophet Muhammad, based on exegesis of the Qurān

17 Çelebioğlu, Muhammediye, 2,7 and 2, 598-6o6, vgm 431A, (oo3) and (322-4). Cf. Heinzelmann, Populäre, $73 \mathrm{ff}$. 
and the prophetic traditions (hadith). At first, he was hesitant, because he thought that a large number of "mevlid books" (mevlid kitäbı) already existed. But eventually, he received the mission directly from the Prophet himself in a dream. Yazıcıoghlı emphasises that his poem is a translation of his own work Maghärib al-zamān (Descendants of time) - a treatise which he had written in Arabic prose. In his preface he also names some of his teachers, among them the Sufi shaykh Hacı Bayram Velī, who was also his guide (mürşid), and the hadīth scholar 'Alī b. 'Abdullāh b. Aḥmed Zeyn el-'Arab. ${ }^{18} \mathrm{He}$ thus points to his Sufi lineage and places himself in a scholarly context as well.

All this information helps to locate his work among Turkish texts on the biography of the Prophet: 1. His reservation vis-à-vis the Mevlid-texts, and his esteem for Qurān and hadìth, 2. The reference to the Arabic version, a larger part of which indeed consists of hadith texts, and 3. The claim that he was commissioned by the Prophet himself, even if the vision of Muhammad in a dream is a well-known topos. ${ }^{19}$

Yazıcıoğlı Muhammed is already mentioned in the earliest biographical encyclopaedias, such as the appendix of Lāmi î's translation of Jāmī's Nafahạt al-Uns $(927 / 1521)$ or Țaşköprizāde's Shakāìik al-Nu'māniyya (965/1558). ${ }^{20}$ Both refer to his famous work Muhammediye and his miracles as a Sufi saint. Taşköprizāde additionally underlines the reliability of his citations of haditth texts. ${ }^{21}$ Both statements confirm the points already brought up by the author himself. Yazıcıoghlı's Muhammediyye combines different poetic forms, such as the mesnevi and the kașide. The text is structured in two parts: 1 . Creation, the history of the prophets, the biography of Muhammad (verses 1-4756); and 2. Eschatology, the day of judgement, paradise and hell (verses 4757-9008).22 It combines narrative and panegyric texts. In the narrative passages the language is a plainly understandable Old-Ottoman-Turkish, typical for fifteenth-century literature. Striking, however, is the vocabulary, which includes rare terms that refer to the wording of the hadith and makes the source of the respective passage recognisable to experts. The author was aware of the fact that these terms were not understandable for a broader audience, and already in the author's

18 Çelebioğlu, Muhammediye, 1, 18-9, Çelebioğlu, Muhammediye, 2, 6o3, Heinzelmann, Populäre, 74.

19 Sirriyeh, Dreams, 2015, 140-57, in particular 146: "Despite the great importance attached to seeing the Prophet in dreams and waking visionary encounters, the phenomenon appears to have been relatively rare in the late medieval period." But the topos as such was still well-known and attested, e.g. in the works of Ibn 'Arabī.

20 Heinzelmann, Populäre, 77, Lāmi'ī, Fütūḥ, 710, Taşköprizāde, al-Shakāàik, 11of.

21 Taşköprizāde, al-Shaḳāik, nof.

22 The enumeration of the verses follows Çelebioğlu, Muhammediye, 1, 95. 
manuscript glosses by the author's hand provide linguistic explanations. ${ }^{23}$ For example the beginning of the chapter on the night journey (mira $a j$ ) of the Prophet reads as follows: ${ }^{24}$

Haber vèrdi resūlü 'llāh ki yatmışdum Ḥaremde ben Ḥatīmde ıżțıāe èdüb èrişdürdi naẓar Allāh İşāda èrdi Cibrā̄il selām èrgürdi Allāhdan Seni Allāh oḳur dèdi buyurmışdur sefer Allāh Ṭutub pes șadrumı yardı ki tā göbegüme èrdi Çıḳardı yüregüm derḥāl daḩı diñle ne-dèr ol şāh

The messenger of God told us, "I slept in the Haram, and when I was lying at the Hațìm, God looked at me. That evening Gabriel brought greetings from God. 'God calls you', he said, 'God orders you to travel.' He seized my chest, and tore it apart down to the belly, and pulled out my heart." Listen, what the king [Muhammad] said.

In these three verses, two terms might have been difficult to understand to the reader - Hațim and $i \dot{z} t i c \bar{a}^{c}$. In the author's manuscript Hațim is explained as "the upper side of the Ka'ba" (Kacbenün uluğı țarafi), and $\iota \dot{\imath t} i c \bar{a}^{c}$ as "lying on one's back" (arkası üstine yatmak). Hatīm is indeed the proper name of a place near the Ka'ba; experts might have recognised $\iota \dot{t} t i c \bar{a}^{c}$ (verbal noun from the Arabic verb idțaja'a) as a reference to a particular hadith: $:^{25}$

According to Katāda, according to Anas b. Mālik, according to Mālik b. Șa'șaa, may God be pleased with them: "The Prophet, god bless him and grant him salvation, told them about the night, 'in which he was made to travel by night' [Q 17,1]: 'I slept lying (mudțaji'an) at the Hațīm' maybe he said 'at the [black] stone', 'when somebody came to me and split me open from here to here' which is from the throat to the pubic hair 'and pulled out my heart."

23 Cf. Heinzelmann, Populäre, 185-92, for a detailed discussion of the vocabulary in the margins of the author's copy and later manuscripts and prints.

24 Çelebioğlu, Muhammediye, 2, 133, vGM 431A, (o9o), Heinzelmann, Populäre, 166.

25 For the Arabic version of the hadīth in Yazıcıoğlı's Maghārib al-Zamān, cf. e.g. manuscripts Süleymaniye Library, Nuruosmaniye 2593, 218a, or Konya Yazma Eserler Kütüphanesi, Akseki 132, 464. This scene is the beginning of a narrative describing the purification of Muhammad's heart. 
In contrast to the narrative passages, which are written in a plain and easily understandable Turkish, the panegyric verses in Yazıcıoğlı's poem are very elaborate. One of the most famous texts is a kașide in praise of the Prophet. ${ }^{26}$ It is müstezād, which is a special poetic form where each of the two semi-verses includes an appendix (ziy äde). The text in question is even more densely structured, since each semi-verse is once more divided by an internal rhyme. Subsequently every verse consists of six sections. The first three verses read as follows:

\begin{tabular}{|c|c|}
\hline Cihānuñ cānı ve cānuñ & $\begin{array}{l}\text { Muhạammeddür çü cānānı } \\
\text { ki ḳāțıddur maḳālātı }\end{array}$ \\
\hline Ol ola çünki cānānı & $\begin{array}{l}\text { nice sevmeye cān anı } \\
\text { ki sātídur delālātı }\end{array}$ \\
\hline Odur cānān yaradan cān & $\begin{array}{l}\text { èdindi çün anı cānān } \\
\text { ki maḥbūb ètdi zāâtına }\end{array}$ \\
\hline Sever anı ḳamu cānān & $\begin{array}{l}\text { odur bu cānlaruñ cānı } \\
\text { ki cāmi'dür kemālātı }\end{array}$ \\
\hline Odur bu cānlaruñ cānı & $\begin{array}{l}\text { odur serverlerüñ hyānı } \\
\text { çün ol sulțān-ı kevneyndür }\end{array}$ \\
\hline Odur gevherlerüñ kān & $\begin{array}{l}\text { o bildi buldı sulțānı } \\
\text { ki șādıḳdur risālātı }\end{array}$ \\
\hline
\end{tabular}

The soul of this world and the beloved of the Living Soul is Muhammad. / What he says is definite.

He is indeed the beloved, why should the Living Soul not love him? / The evidence is obvious.

It is the Living Soul, Who created the beloved and adopted him as His beloved. / He made him His beloved.

All souls [all beloveds] love him. He is the living soul of the souls. / Whose perfections are encompassing.

He is the living soul of all living souls, he is the sovereign of all princes. / Because he is the sultan of both worlds.

He is the mine of all gems. He found and knows the sultan. / His message is true.

The kașide plays on Sufi terminology - Muhammad is characterised as the "living soul of the world" (cihānuñ cānı) and the "beloved of the Living Soul (i.e.

26 Heinzelmann, Populäre, 95, cf. the short hagiography, which is part of all lithographic Muhammedìye prints since 1262/1846 for a reference to this kașide as one of Yazıcıŏll's most famous texts. 
God)" (cānuñ cānānı). Additionally, the poem focusses on the trustworthiness and definitiveness of Muhammad's words.

\subsection{The Interrelation of Narrative, Rhetorical, and Graphic Aspects in Yazıcıoğlı's Muhammedīye}

Compared with the other two poems, Yazıcıoğlı's Muhammedīye stands out due to the rich variety of graphic elements, which visualise narrative and rhetorical aspects of the text. Three main types are to be distinguished: the first follows the author's copy, which was venerated as a saint's relict, fairly closely. The second type is limited to a short period of approximately one century and is characterised by specific methods to visualise the rhetoric of the text. The third type is preserved in only two illustrated manuscripts, which both date from the first half of the nineteenth century. These latter illustrations, however, had a remarkable influence on the Muhammediye prints in the nineteenth and early twentieth centuries.

\subsection{The Author's Manuscript and Its Influence on the Format of Later Copies}

The author's manuscript of Yazıcıoğlı's Muhammediye was preserved at his tomb in Gelibolu (Gallipoli) until the Second World War. In 1942, it was transferred to the archive of the Directorate General of Pious Foundations (Vakiflar Genel Müdürlügü) in Ankara. ${ }^{27}$ The location of this copy at the saint's tomb in Gelibolu and evidence for its veneration by pilgrims have been documented in historiographic and hagiographic texts since the sixteenth century. ${ }^{28}$ The manuscript is a draft with numerous additions and emendations in the author's hand. One double page shows scorch marks, which were interpreted as traces of the saint's miracle. A deep-drawn sigh, which he gave out of his enormous love for God, had set the page on fire. The manuscript also contains a sketch of the "banner of praise" (liva a el-hamd), which Muhammad will carry ahead of the believers when entering paradise on the day of judgement, and a calligraphy of the three lines which are written on the banner - the formulas of invocation (besmele), praise (hamdele), and creed (şehādet). The page with the banner bears traces of touching or kissing; it was obviously an object of an increased degree of veneration - probably because of its visualisation of the prophet's role on the day of judgement.

The banner of praise was seen as part of the (author's) text by most copyists and hence included in their manuscripts. In a smaller number of cases some space was left blank to complete the page later, or only the three lines were written in the sülüs-like calligraphy of the author's copy. The famous scholar

27 Çelebioğlu, Muhammediye, 1, 41, Heinzelmann, Populäre, 322.

28 Heinzelmann, Populäre, 322-33. 


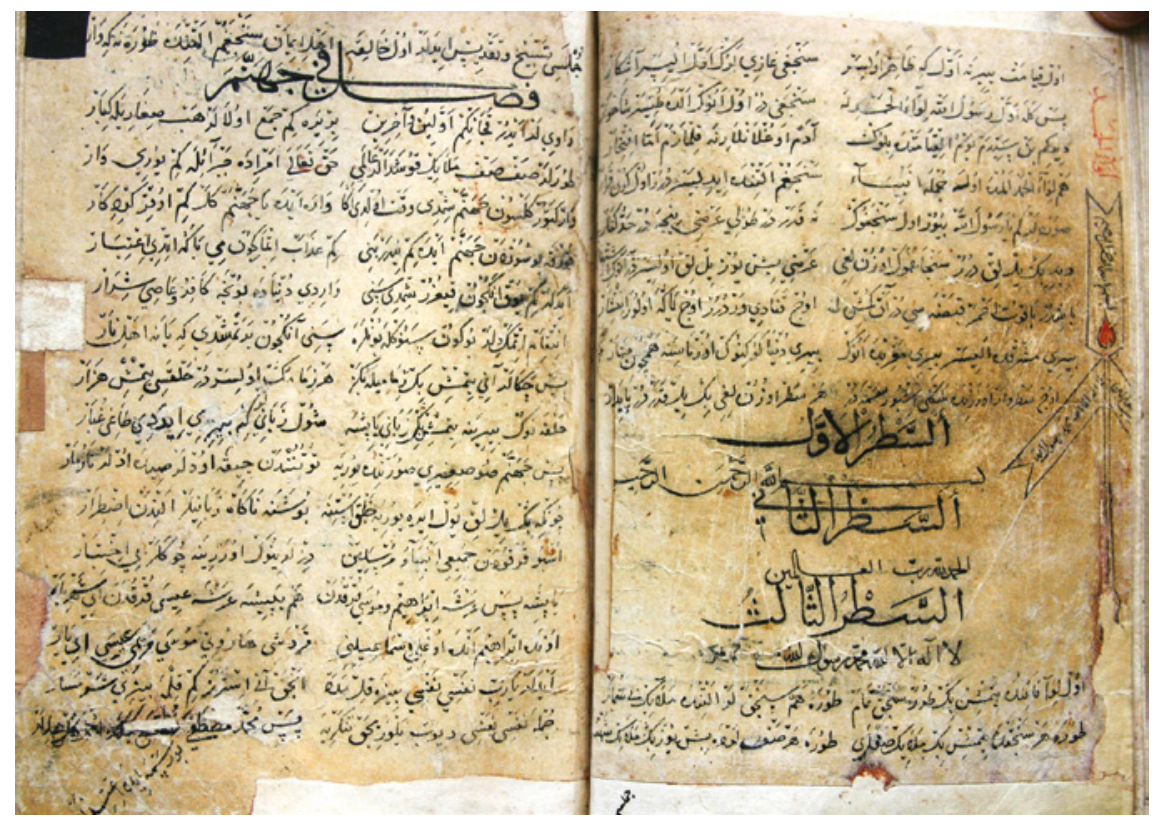

FIGURE 19.2 Yazıcıoğlı, Risāle-i Muḥmmedīye, author's copy, Vakıflar Genel Müdürlüğü, Ankara, MS. 431/A, fol. 221, banner of the Prophet on the right margin

and Sufi shaykh Bursalı İsmācil Ḥaḳkı, who had copied Yazıcıoğlı’s manuscript during his stay in Gelibolu 1121/1709, even wrote a marginal note next to his own sketch, in which he explicitly pointed out that it corresponded to the original. ${ }^{29}$

Even if the sketch of the banner is included in most manuscripts, its overall shape varies considerably: some images remain close to the original, some are more elaborate, some are more naturalistic, and some adopt a totally different form. In a copy from 1057/1648, the banner of praise is depicted in the shape of a tulip, which again bears clear traces of touching and kissing. ${ }^{30}$ The manuscript is therefore a telling example showing that the "banner of praise" was an object of veneration not only in the author's manuscript but also in some later copies. Sitting or standing in front of these images, the readers, viewers, and devotees came into contact and touched a copy of the Sufi shaykh's sketch, which released a blessing on its own. At the same time, the sketch of the banner - and object of veneration - is a visualisation of Muhammad and his intercessory role on the day of judgement.

29 Bursalı İsmāôil Ḥaḳkı documented narratives about the manuscript in several marginal notes in his copy. These were orally transmitted at the tomb, cf. Heinzelmann, "Anfänge", and Heinzelmann, Populäre, 322-25.

30 Cf. Heinzelmann, Populäre, 323, concerning Bursalı İsmācîl Ḥaḳkıı's marginal notes about pilgrims touching or kissing the author's manuscript. 


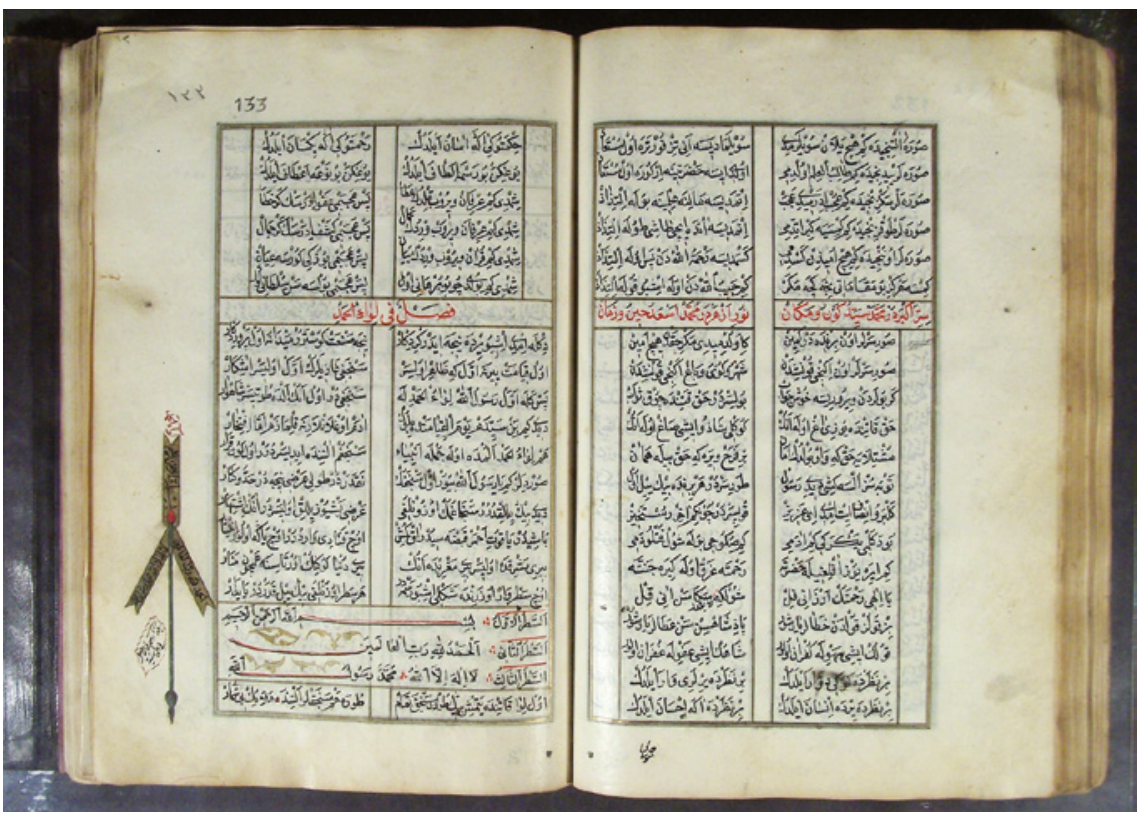

FIGURE 19.3 Bursalı İsmāīl Ḥakḳı's copy of Yazıcıoğlı, Risāle-i Muḥmmedīye, İnebey Kütüphanesi, Bursa, Genel 58 (1121/1709), 133a; copy of the banner of the Prophet on the left margin with reference to the original

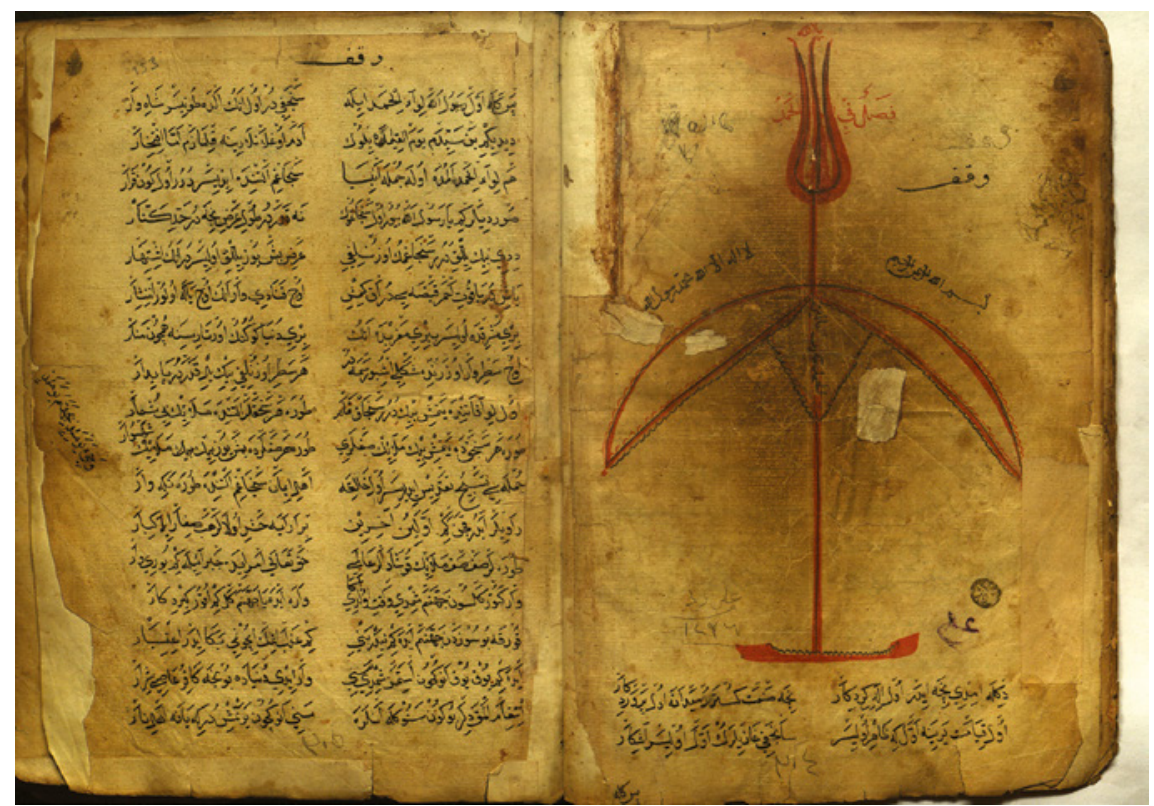

FIGURE 19.4 Risāle-i Muhammedīye, Banner of the Prophet, Ankara, Milli Kütüphane, Ankara, B 96o (1057/1648), 152b 


\subsection{The Fakīh Tradition}

A corpus of Muhammediye-manuscripts from the sixteenth century was according to the colophons - produced in a fakih context; a person in the patronym of the copyist bears the title fakìh (scholar of Islamic law", or in OttomanTurkish in a broader sense "religious expert). I therefore call them "the fakìh manuscripts". These are characterised by a distinctive graphic layout: the text is structured by calligraphic figures, which visualise the poetics and rhetoric of Yazıcıoğlı's poem - e.g. rhyme, assonance, and iteration. Iterations at the beginning of subsequent verses or rhymes are in most cases written only once and the rest of each of the dependent semi-verses branches out from this single word or phrase. The verses thus assume the shape of a fan (see Figure 19.5 below). Additionally, iterations - e.g. the pronoun "He" for God - are written in red or in different colours, which helps to structure the text during recitation, especially in passages particularly dense with poetic figures. The manuscripts are not copied in one of the classic ductuses of Arabic calligraphy, but still in an attractive, fluent hand typical of the sixteenth century.

One of these manuscripts is preserved in the library of the private chamber of the Sultan (hāṣṣ odası) at the Topkapı-Palace in Istanbul (TSMK Hs 93). It

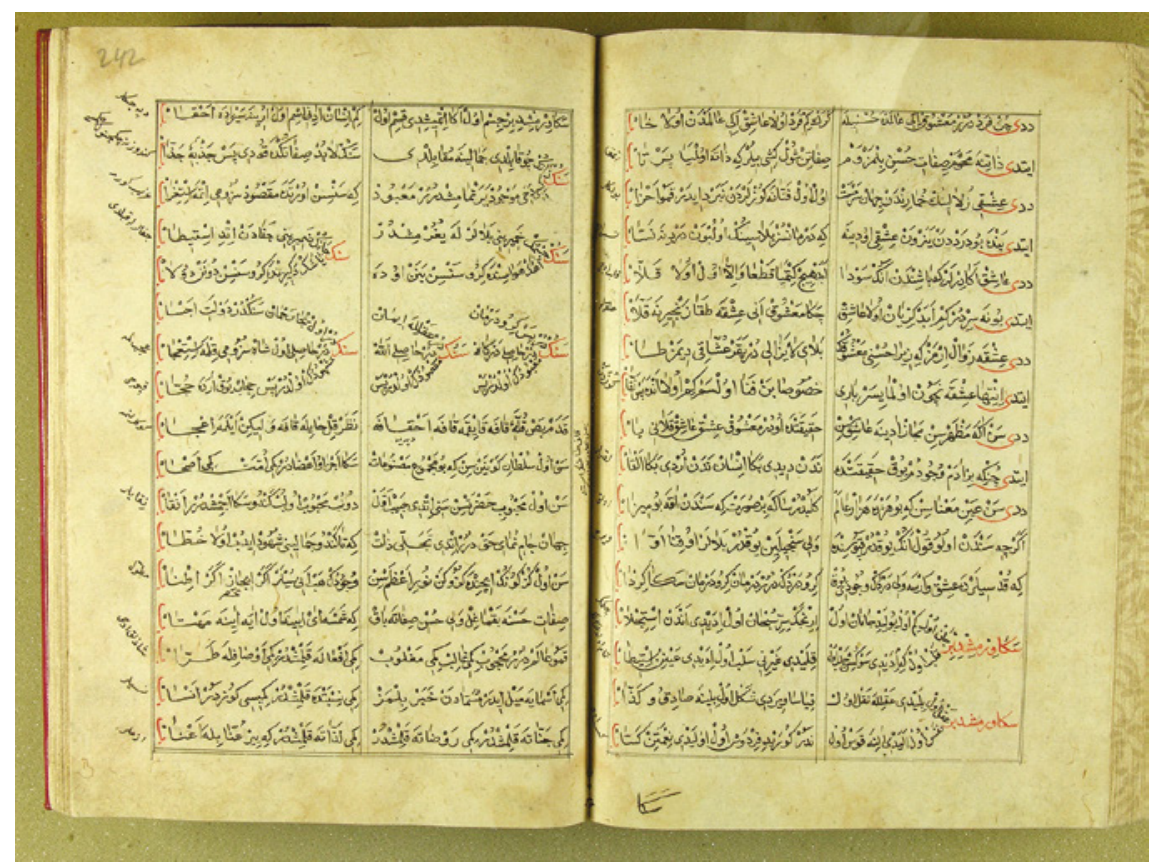

FIGURE 19.5 Risāle-i Muḥammedīye, Fan-shaped arrangement of verses, Istanbul, TSMK HS 93, 241b-242a 


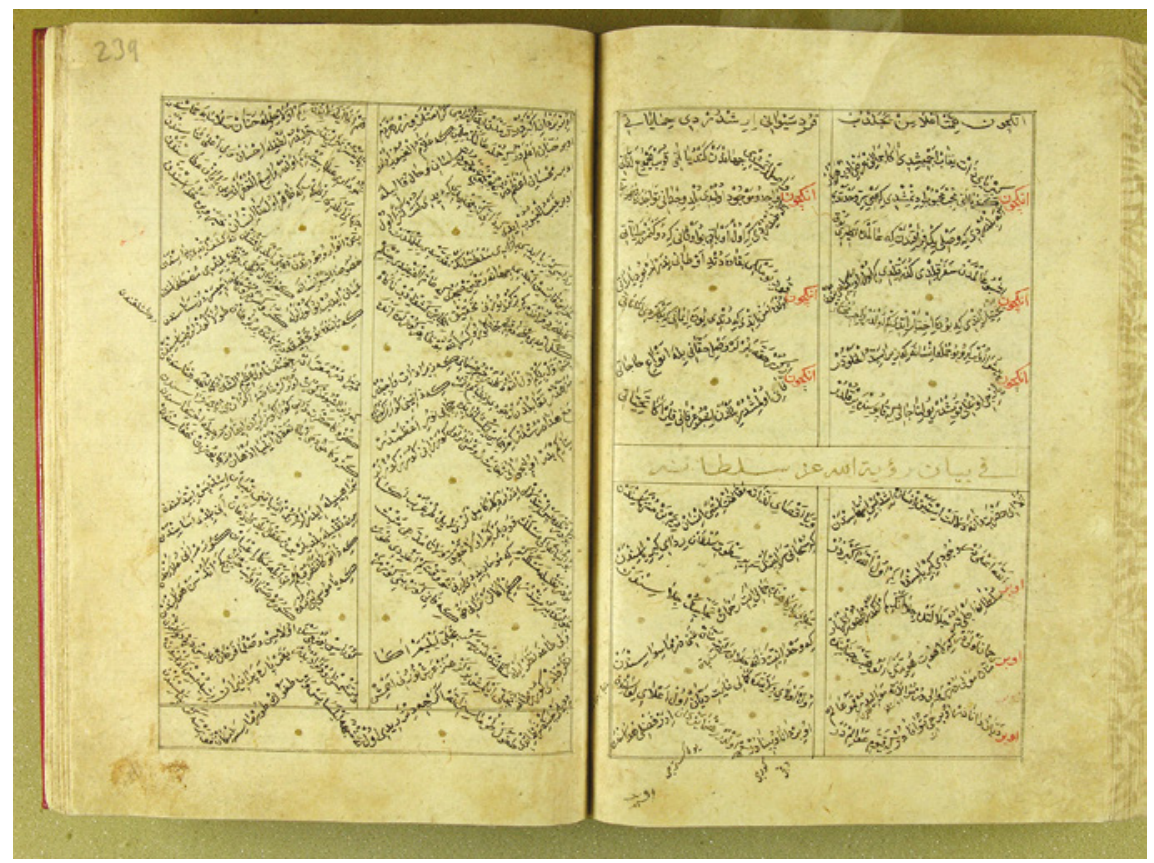

FIGURE 19.6 Risāle-i Muhammedīye, oval, eye-shaped calligraphic arrangement of verses, with a dot in the middle of each oval visualizing the Prophet's vision of God, Istanbul, TSMK HS 93 (908/1502), 238b-239a

was copied 9o8/1502 by a certain Ḥacı Ya ḳūb b. Mușțafā Fakịh. Apart from the title faki $h$ in the copyist's patronym, we have no information about the social context or location. Later, the manuscript was donated as an endowment to the private chamber by a certain Sarıkçı 'Alì Ağa, key bearer of the Sultan, who was by his rank one of the privileged few to be allowed to enter this part of the palace. ${ }^{31}$

The manuscript TSMK HS 93 shows the characteristic aspects of the fakih tradition - the fan-calligraphy visualising rhetorical figures. Though most of the manuscripts which originate from a fakith context feature elaborate illumination, the copy, which later ended up in the Sultan's palace, is extraordinary in terms of the materials used (the headings and illuminations in gold and various colours). Additionally, it is the most impressive example among the fakih manuscripts for the interrelation of theme, rhetoric and graphic. All the fakih manuscripts use an oval, eye-shaped calligraphy of two subsequent semiverses, with a dot in the middle of the oval, to visualise Muhammad's vision 
of God (rüyet Allāh). They also use a netted, interwoven shape of the semiverses to visualise the müstezād pattern of the panegyric kașide. Special about TSMK HS 93, however, is the combination of both. Besides the first narrative of Muhammad's vision of God in the chapter on the night journey, Yazıcıoğlı brings the topic up a second time in the eschatological part of his poem, following and complementing the panegyric kașïde. In TSMK HS 93, a double page is filled with the netted interwoven structure of the kașide, which also picks up the eye-shaped arrangement of the semi-verses. ${ }^{32}$ On this double page the calligrapher not only visualises the rhetoric of the poem, but also connects and emphasises the author's praise of the magnitude and beauty of Muhammad.

\subsection{The Illustrated Versions of the Nineteenth and Twentieth Centuries}

In March 1822 a certain Nașụ̄ b. Ṣaliḥ finished a copy of Yazıcıoğlı's Muhammedīye, which is outstanding due to its illustrations (DKM, Maārif 'Āmma Turkī Țal'at 22). The manuscript contains fifty schematic miniatures, which depict the narrative of Muhammad's biography as well as the eschatological chapters in Yazıcıoğlı's work. It is the first manuscript copy of a graphic tradition, which had a significant influence on the printed editions of Yazıcıoğlı's work. But it is probably already a copy of an earlier version. ${ }^{33}$ The colophon has neither a localisation nor any information about the social background of the copyist. The manuscript is part of the collection of Ahmad Tal'at (d. 1347/1927) - a member of the Turkophone elite in Egypt - which is now preserved in the Egyptian National Library. ${ }^{34}$

Some of the illustrations are based on earlier patterns - e.g., the sketch of the "banner of praise", which is part of the author's text, or sketches of the Prophet's relics or topographic diagrams in the chapters about the biography of the Prophet, which are most probably adapted from the manuscripts of other texts. ${ }^{35}$ The larger part, however, is to my knowledge unprecedented, as it uses small circles representing the Prophet Muhammad and his contemporaries. These circles are situated in schematic sketches of buildings and places. The

32 TSMK HS 93 (908/1502), 238b-239a.

33 DKм Ma'̄āif 'Āmma Turkī Ṭal'at 22 includes a few short citations from Bursalı İsmā̄̄il Hakḳı's commentary Ferah er-Rüḥ. It is also in the printed edition of İsmāîl Hakḳı's commentary, not in the printed edition Yazıcıoğlı's original, where we find the earliest published version of the illustrations. This might give us some - still rather vague - evidence that the illustrations are originally from İsmācîl Hakḳı’s commentary.

34 Heinzelmann, Populäre, 29, Sayyid, Dār al-kutub, 6o, Ziriklī, al-Alam, 1:137.

35 On miniatures of the Prophet's relics or the topography of Mecca and Medina in devotional texts and prayer manuals, cf. Witkam, Vromheed, passim, Witkam, "The Battle", passim, Gruber, “A Pious Cure-All”, passim, Maury, “Ottoman Representations”, passim. 
circles may recall of name tags in diagrams visualising the lineage of ancestors (silsile), but they are something new as part of illustrating a narrative. In the same manuscript we have schematic illustrations of paradise and hell in the eschatological chapters of the book.

A closer look at four of the illustrations reveals the different strategies to visualise the dynamic of the narrative. The first two pictures depict Muhammad's birth by a schematic sketch of a domed building, which contains two circles labelled Ämine (the name of Muhammad's mother) and resül 'aleyhi s-selām (the Prophet, peace be upon him). On the following page, a topographic sketch of the Kaba illustrates the verse that describes that Muhammad prostrated himself in front of his Lord (çünki țogdı anasından secde kıldı rabbine), when he left his mother's body. ${ }^{36}$

The sketch of the Kacba is one of those based on earlier patterns, which can be found in manuscripts of other texts or on tiles, too. ${ }^{37}$ The two sketches are part of a single narrative element, i.e. Muhammad's reorientation at his birth from his mother to God - in the Turkish verse apparent due to the two cases,

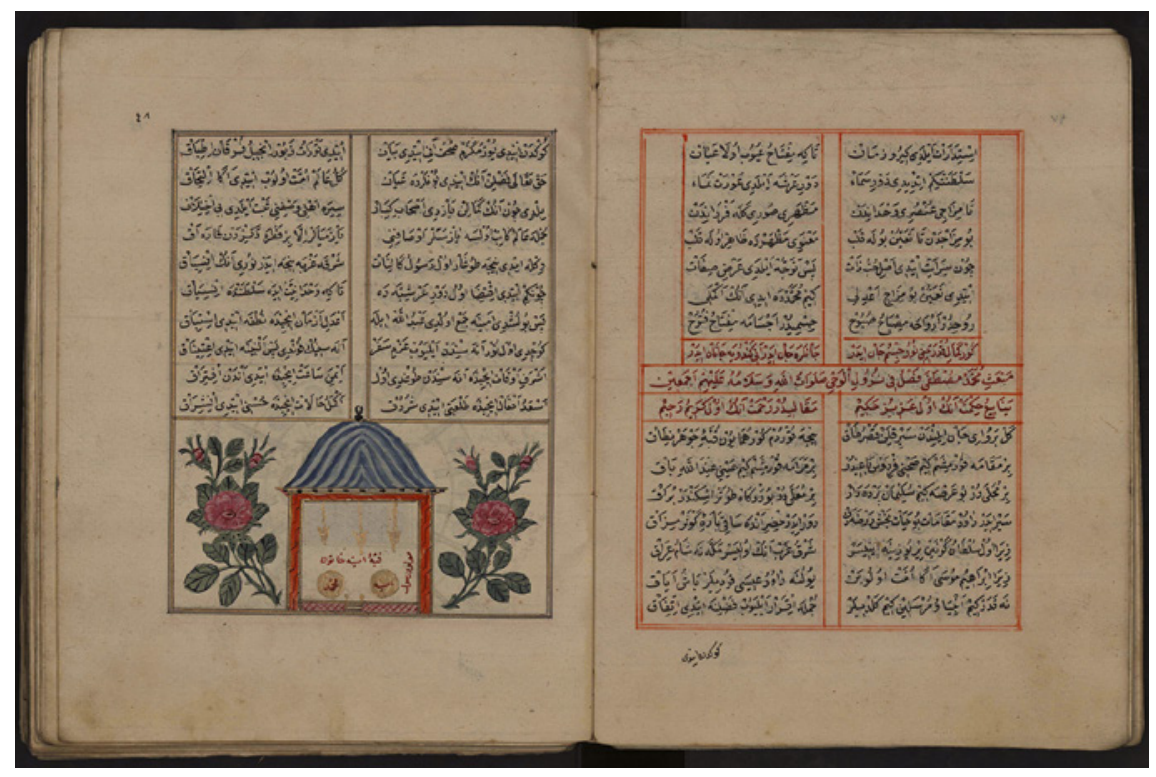

FIgURE 19.7 Risāle-i Muḥammedīye, Birth of the Prophet, Dār al-Kutub al-Miṣriyya (DKM), Cairo, Ma'ārif 'Āmma Turkī Ṭal'at 22, 48a

36 DKм Ma'ārif 'Āmma Turkī Țal'at 22, 48a-b.

37 DKм Ma'ārif 'Āmma TurkīṬal'at 22 and sk İzmir 6o1. Cf. Maury, “Ottoman Representations”, passim. 


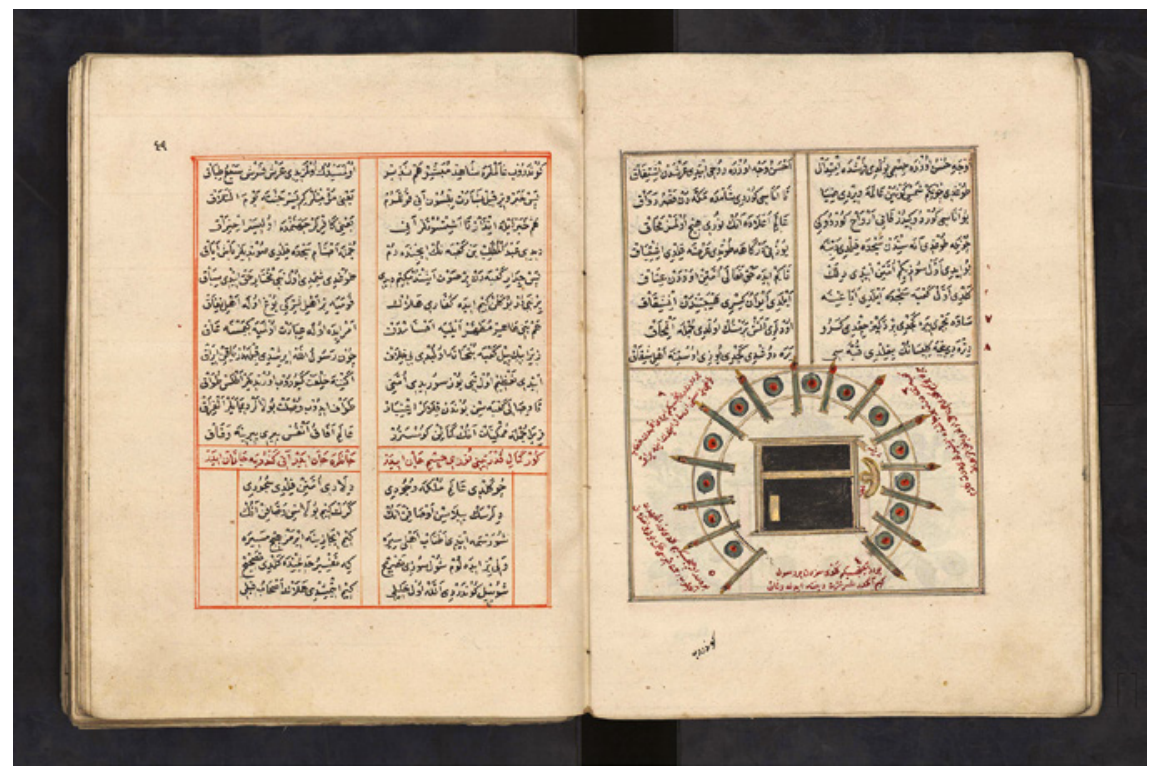

Figure 19.8 Risāle-i Muhammedīye, Prostration of the new-born Prophet at the Ka'ba, Dār al-Kutub al-Mișriyya (DKM), Cairo, Macārif 'Āmma Turkī Ṭal'at 22, 48b

ablative "from his mother" (anasindan) and dative "to his God" (rabbine). In the printed versions the two pictures are arranged in one line, side by side. In the print from $1300 / 1882-3$ - and in later prints - the picture(s) are added captions, which read "Āmine", "Picture of the Ka'ba", and in the middle between the two the inscription "The Prophet". It is striking, however, that the house, where Āmine gave birth, turned into her tomb - showing a sarcophagus inside. Muhammad remains in this version present only in the caption, and the perspective is now that of contemporary believers looking at two locations for their pilgrimage. ${ }^{38}$

Equally remarkable is the illustration in the chapter on the Prophet's night journey, which depicts the moment of Muhammad's vision of God. Within a rectangular frame, three circles are arranged in a triangle; in the lower two corners two silver circles are labelled as "Gabriel" and "Messenger of God", respectively. ${ }^{39}$ In the middle of the upper side of the rectangle, two thin concentric golden circles remain unlabelled, obviously representing God. The text of the salutation formulas links the three circles and can be read as an illustration of the dialogue.

$38 \quad$ Muhammediyye, print 1300, 76 .

39 DKM Ma'ārif 'Āmma Turkī Țal'at 22, 66b. 


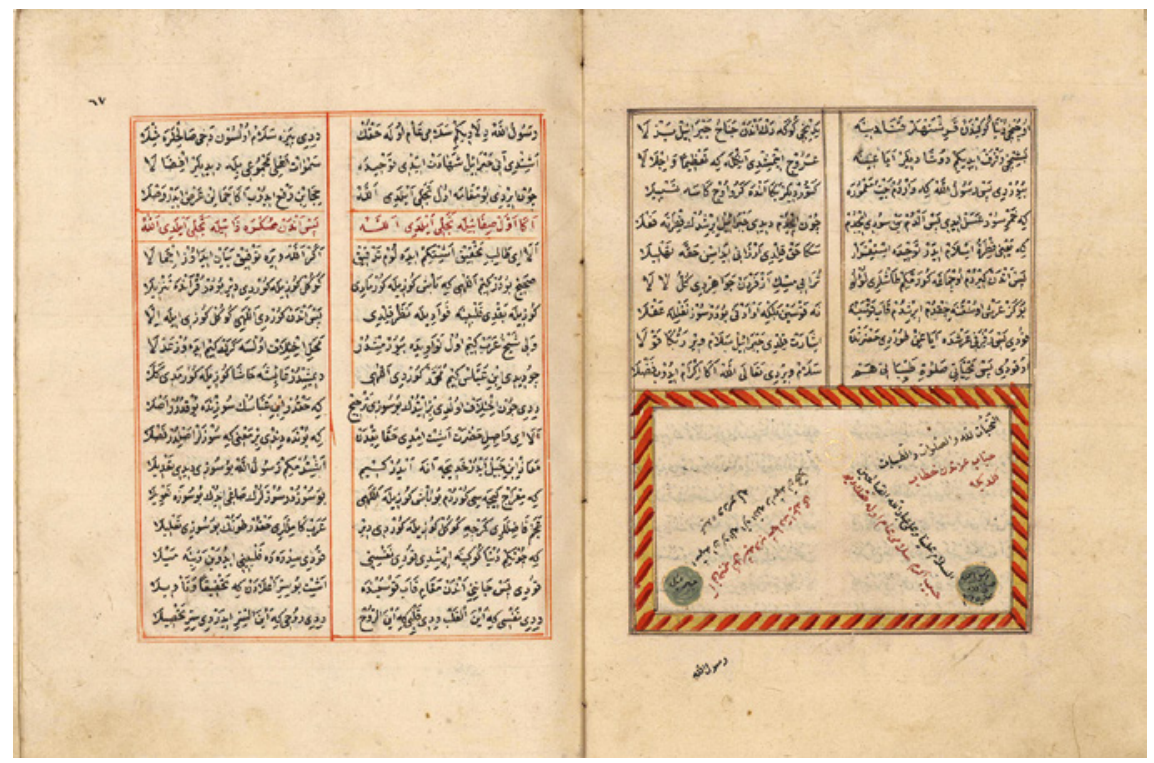

FIgure 19.9 Risāle-i Muhammedīye - The Prophet's encounter with God during the mi'rāj, DKM, Cairo, Ma'ārif 'Āmma Turkī Țal'at 22, 66b

In the chapter about the migration to Medina (Hijra), the dynamic of the narration is emphasized by a special layout - two circles labelled "Prophet" and "Ebū Bekir" peregrinate across the pages, two thin lines marking their way. For example, the verses about Muhammad and Abū Bakr hiding from their pursuers is accompanied by a picture of the cave at Mount Thawr as an abstract rectangle. ${ }^{40}$ The circles of the two protagonists wander from the right to the left side of the page, change their direction several times and finally pass the rectangle. At the entrance of the rectangle the abstract representation of the spider is located, which by God's miracle hastily built its web to hide the two, and a tree, which grew to hide the entrance. Above the rectangle two circles are labelled "Surāka" - one of the pursuers - and "Satan".

The representation of the Prophet and his contemporaries by circles obviously reflects a hesitation to add figural or naturalistic pictures to Yazıcıoğlı's text. Still, they indicate that there existed a desire to visualise the narrative about the Prophet, which had been transmitted for almost four centuries with only one single illustration - the "banner of praise". To my knowledge there is only one other manuscript copy of Yazıcıoğlı's Muhammedīye, which includes 


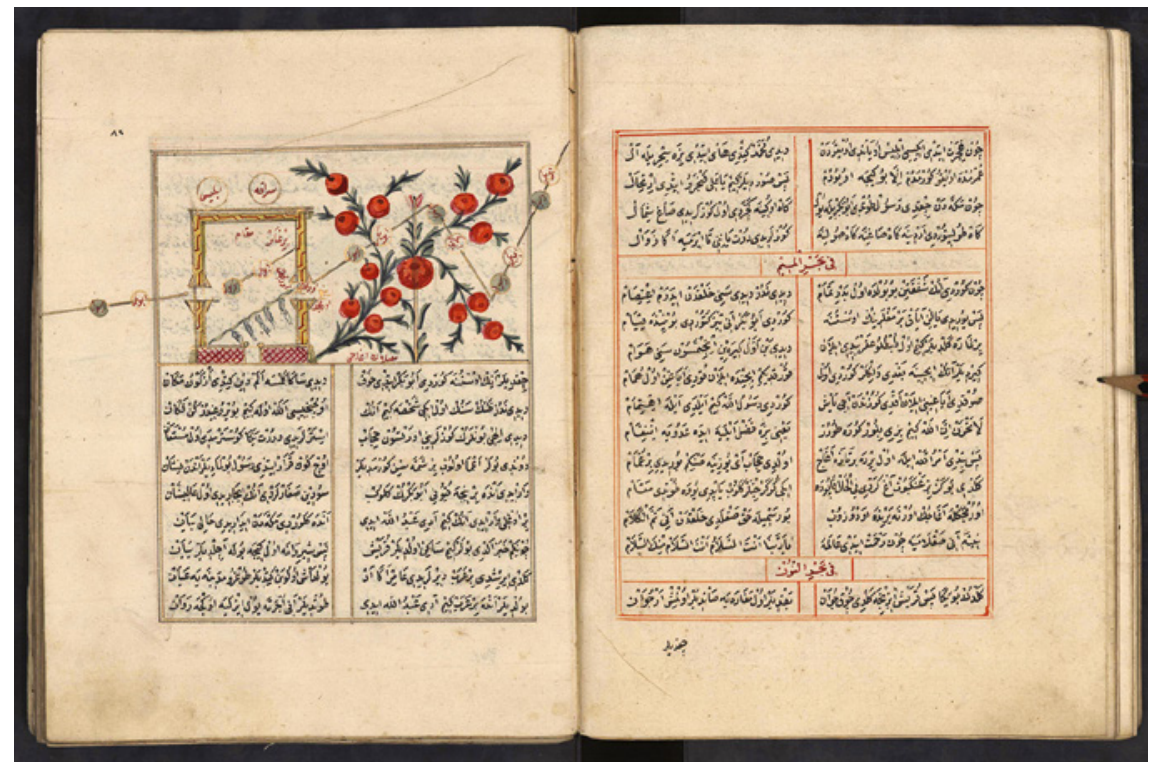

FIGURE 19.10 Risāle-i Muhammediyye - The Prophet's and Abū Bakr's refuge in the cave during the Hijra, DKM, Cairo, Ma'̄ārif 'Āmma Turkī Ṭal'at 22, 82a

the fifty illustrations (sK İzmir 6o1, 126o/1844) ${ }^{41}$ The structure is very similar, but the circles in some of the pictures are situated in a scenery that presents a certain degree of naturalism. Still, the enormous influence on the printed editions is striking. In 1258/1842 the printing shop in Bulāk/Cairo published Ferah er-Rūh - Bursalı İsmāīl Ḥaḳkı’s commentary on Yazıcıoğlı's Muhammedīye with the illustrations in question. It was printed with movable letters, but the pictures were integrated as lithographic prints. İsmācil Ḥaḳıı's commentary was reprinted with the same illustrations in 1294/1877 in Istanbul. In contrast to the manuscript DKM, Maārif 'Āmma Turkī Țal'at 22, the circles in the prints are not labelled, which means that the interpretation of these printed pictures required more imaginative power.

Between 1258/1842 and 1326/1909 more than 29 lithographic prints of Yazıcıoğlı's Muhammedìye were published in Istanbul, and between $1845^{-1903}$ more than ten prints with movable types were published in Kazan. ${ }^{42}$ These prints all included the illustration of the "banner of praise" and additionally in

\footnotetext{
41 Heinzelmann, Populäre, 2ooff.

42 The numbers refer to my catalogue from 2015, Heinzelmann, Populäre, 451-7. Since then I have seen additional prints at old booksellers.
} 


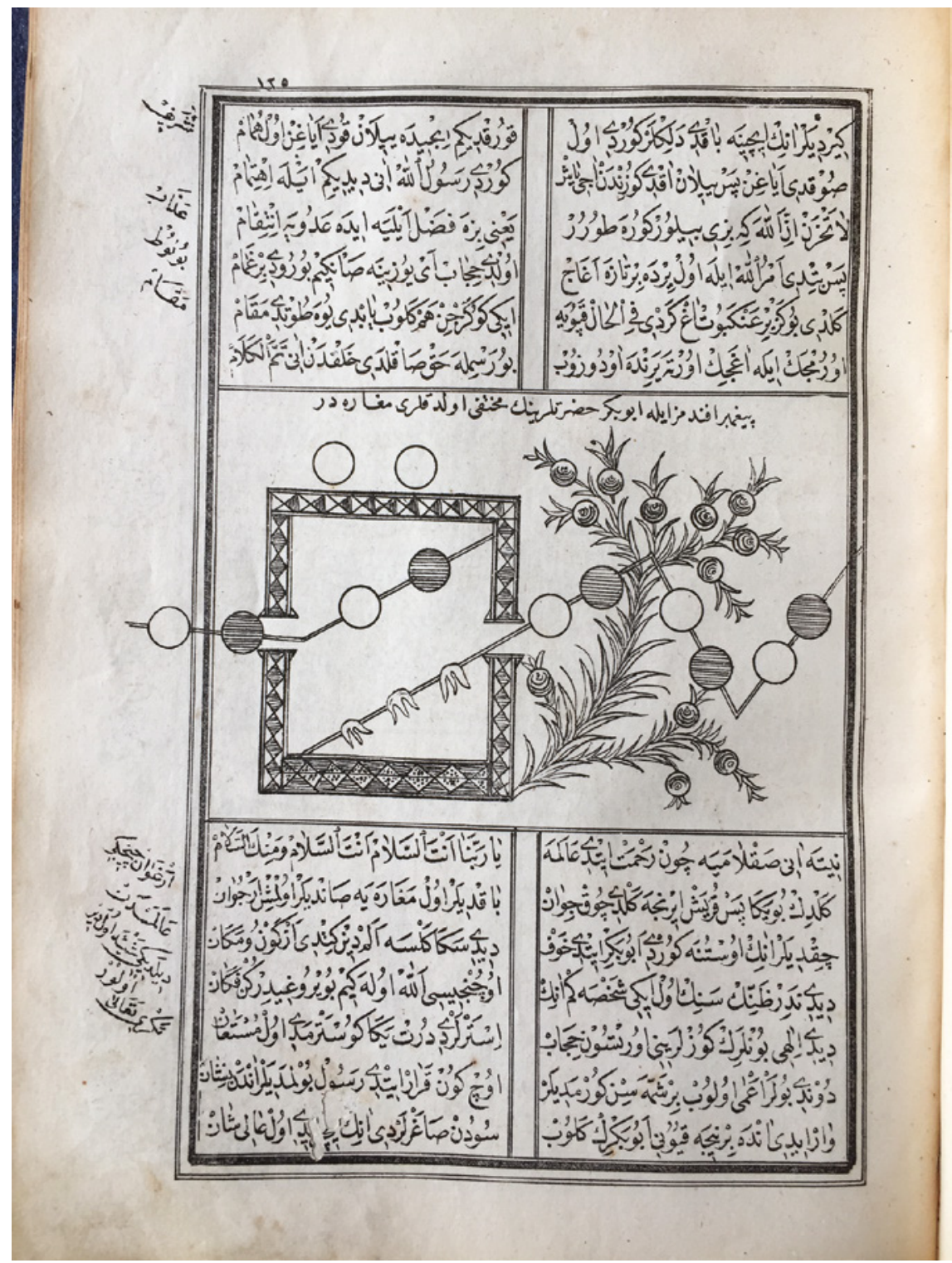

FIGURE 19.11 Risāle-i Muhammedīye - The Prophet's and Abū Bakr's refuge in the cave during the Hijra, from a print copy, Istanbul 1294/1877, 125 


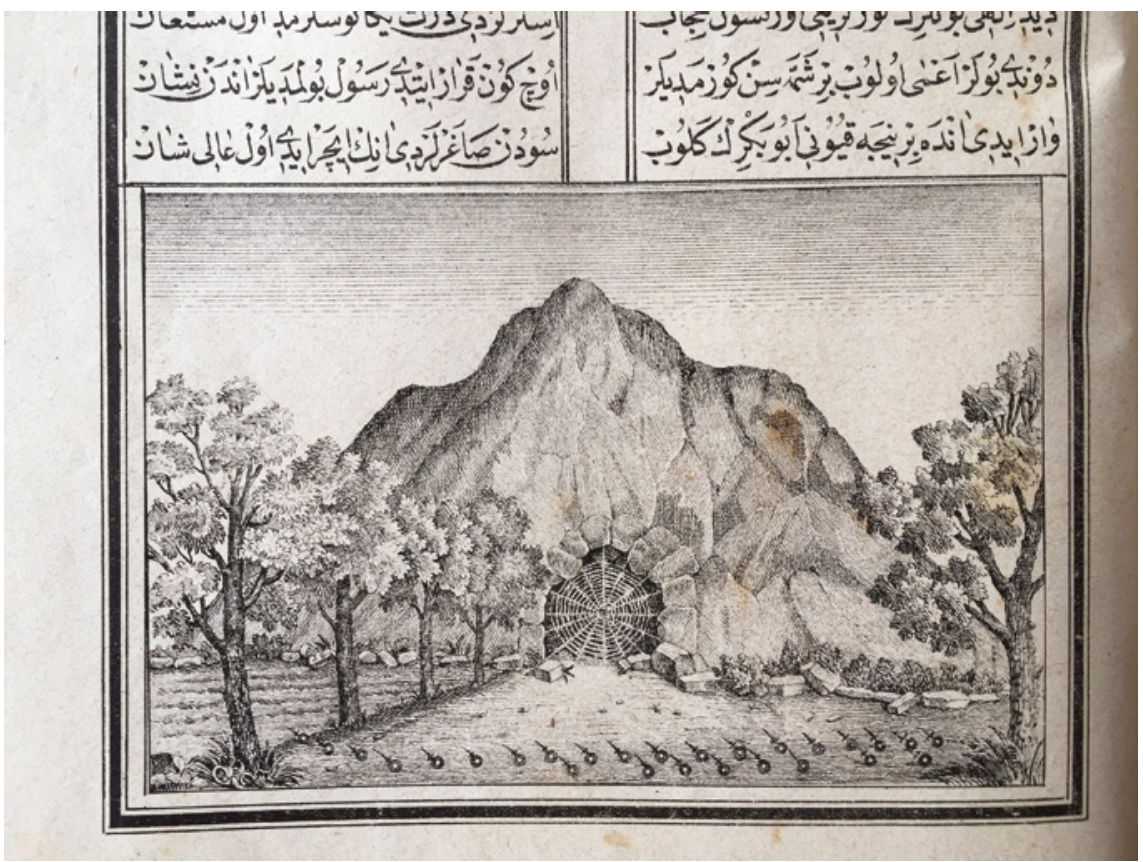

FIGURE 19.12 Risāle-i Muhammedīye - The Prophet's and Abū Bakr's refuge in the cave at mount Thawr during the Hijra, hidden behind a spider's web; printed version, Istanbul 130o/1882-3, 129

a preface a schematic sketch of the different levels of paradise. The latter followed a pattern from manuscripts of Erzurumlu İbrāhīm Hakḳı's Ma'rifetnāme (Book of Gnosis). ${ }^{43}$ This synthesis of two graphic patterns - the banner of praise from the Muhammediye-tradition and the levels of paradise from a different text - was, in contrast to others, obviously successful. These prints, however, were soon outstripped by the richly illustrated version, which adapted the sketches from the edition of İsmā'il Hakḳı's commentary from Būlāk. Starting from the tenth edition from 1279/1863 all the lithographic prints of Yazıcıoğlı's Muhammedīye in Istanbul included these illustrations, in which the circles representing the protagonists were again not labelled.

In 1300/1882-3 the first edition with a variant of the illustrations was published in Istanbul. More prominent than in the manuscript sk İzmir 6 or are the circles, which represent Muhammad and his contemporaries, embedded in a

43 On Erzurumlu İbrāhīm Ḥaḳkıı and his Márifetnāme cf. Çağrıcı, "İbrâhim Hakkı Erzurumî”; Topaloğlu, "Mârifetnâme". On the diagrams in the Ma'rifetnāme cf. Karamustafa, "Cosmological diagrams"; Gruber, "Signs of the hour", 54 f. 
naturalistic scenery or in buildings foreshortened for perspective. The illustration of the migration to Medinna, in which Muhammad and Abū Bakr hide in a cave, presents a naturalistic scenery, too. At the entrance of the cave, we can clearly recognise a spider web. In the scene of Muhammad's night journey, we see a small white circle on a flying carpet above a naturalistic desert landscape. ${ }^{44}$ The circles for Gabriel and God are lacking. The artist seems to have expected less imaginative power from his readers; however, the contrast between the schematic symbol of the circle and the naturalistic environment remains apparent.

\subsection{The Manuscripts DKM Ma'ārif 'Āmma Turkī Tal'at 22 and sK İzmir 6 or and the Two Prints of İsmã $\bar{\imath}$}

Hakkı's commentary also includes five hilye-illustrations - the hilye of the Prophet in the chapter on his passing and funeral, and those of the four Rightly Guided Caliphs in their respective chapters. The latter are adaptations of the Prophet's hilye with a description of their physiognomy in the central circle.

These hilye diagrams constitute a germane transition to the next section on the Hilye-i Hākannī. In the case of the Muhammedīye and its commentary, these hilye diagrams are more than a straightforward illustration - they are more likely the interpolation of another text, since the diagrams include two hadith texts, namely a hadith about the meaning of the Prophet's hilye and the hadith describing his physiognomy. ${ }^{45}$ The hadith on the meaning of the Prophet's hilye is, moreover, translated into Turkish verses imitating Yazıcıoğlı's style. The texts are neither part of Yazıcıoğlı's original or traditionally transmitted Muhammedīye text, nor of İsmāîl Ḥaḳḳ's commentary. ${ }^{46}$ In fact the pages in question document a synthesis of different traditions to visualise Muhammad.

In the manuscript DKM Ma'ärif 'Āmma Turkī Tal'at 22, heavy traces of touching or kissing indicate that in this case the hilye played an important role in the veneration of the Prophet. The printed versions of Yazıcıoğlı's Muhammedìye, however, adapted the illustrations without the hilye diagrams.

\footnotetext{
44 Refref is here interpreted as flying carpet. For refref as a means of travel on Muhammad's night journey cf. Dehkhodā, et al. Loghatnāme-i Dehkhodā, s.v. "rafraf". The depiction as flying carpet needs further research.

45 See the section about the Hilye-i Huăkānì below.

46 Cf. the author's manuscript of the Yazıcıoghlı's Muhammedīye, Vakıflar Genel Müdürlüğü, Ankara, 431A, ca. 196-99 (the manuscript is not paginated, therefore these are the numbers of the slide) and the author's manuscript of İsmāîl Hakḳı's Ferah er-Rūḥ, İnebey Kütüphanesi, Bursa, Genel 61, ca. 593-626.
} 


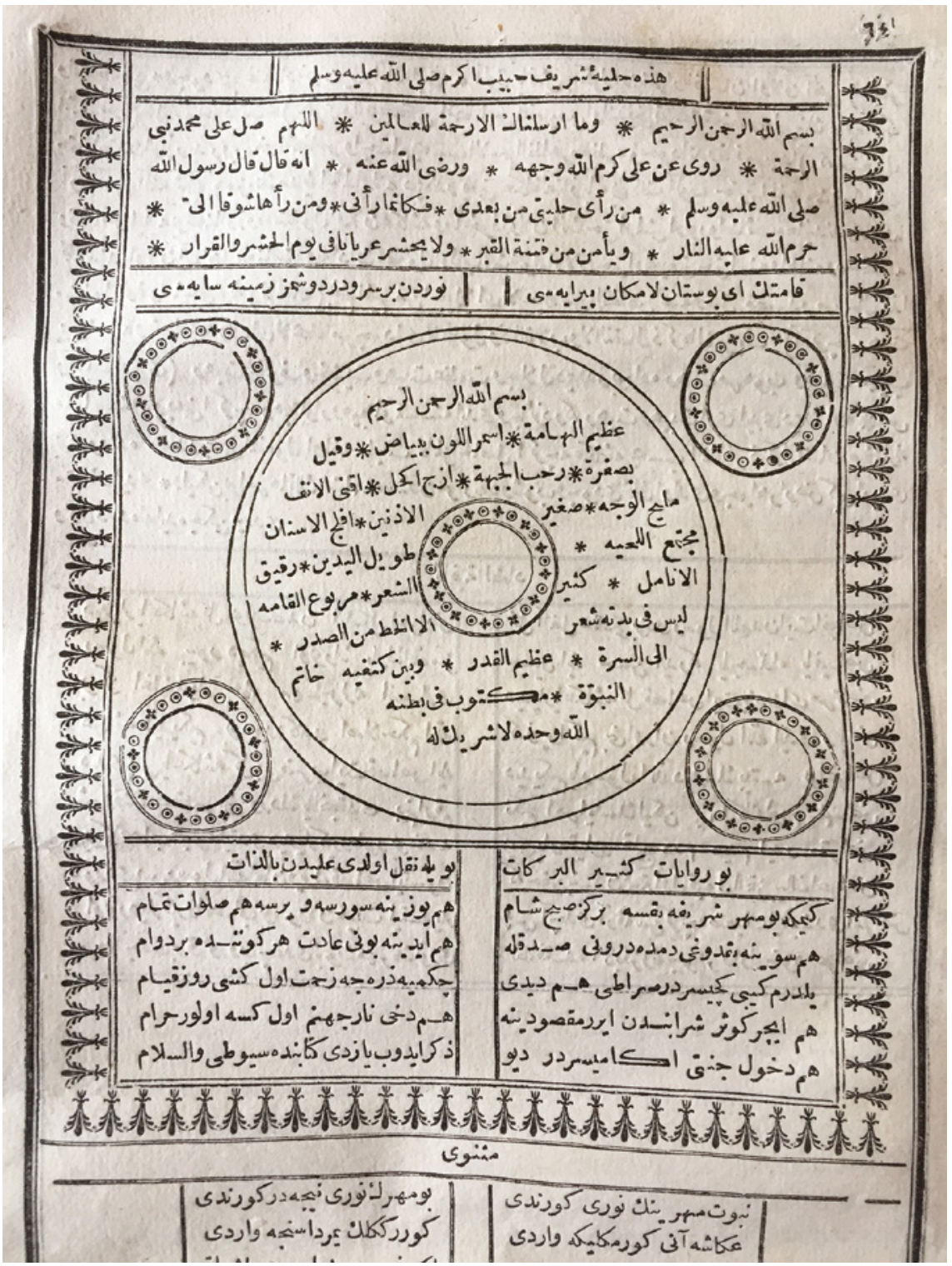

FIGURE 19.13 Graphic of the hilya in Bursalı İsmāīil Hakḳīs, Ferah er-Rūh - hilye text, printed Cairo 1258/1842, 64 
The author of the Hilye-i Hākanni lived more than 150 years after the other two poets. His text was widely read, yet never as popular as Yazıcıoğlı's. Hākāanī Mehmed Beg (d. 1015/16o6-7) was an official in the Ottoman administration. ${ }^{47}$ His Hilye includes a dating (1007/1598-9) and signature of the author under his pen name - Hākāāni The author and his work are mentioned in biographical encyclopaedias already in the seventeenth century. Even if there are some differences over his family background, they agree concerning his career: he held several offices at court and in the provincial administration (including the position of a sancak governor). ${ }^{48}$ The text is based on al-Tirmidhī (d. 279/892), al-Shamāil al-muhammadiyya. This author compiled - alongside his comprehensive hadith collection - this smaller compendium devoted to hadith texts about the physiognomy and character of the Prophet. ${ }^{49}$

The title - Hilye - refers to a hadith, quoted in the introduction, which relates that the Prophet presages the effect which a dream vision of his "sheen" (hilya) will have: ${ }^{50}$

It is passed down according to 'Alī b. Abī Ṭālib, who said: "The Prophet said, 'if anybody sees my hilya, after I have passed away, it is, as if he sees me. And from those, who see it having a true desire for me, God will withhold the fire, and he will save them from the torment of the grave, and they will not be judged naked on the day of judgement.' And according to another tradition he said 'nude on the day of judgement".

Tirmidhī's collection al-Shamāil al-Muhammadiyya contains a whole chapter about dream visions of Muhammad - especially the famous saying "whoever sees me in his dream, has seen me in reality, because Satan is not able to take my shape" (man ra'ānī fì l-manām fa-ḳad ra'ānīfa-inna al-shayțān lā yatamaththalu $b \bar{\imath}){ }^{51}$ Although the hadith at issue cannot be found in Tirmidhi's collection, it was central for Hāạānī's text.

In his poem, Hākāānī translates, paraphrases and comments on nine more hadith texts depicting the physiognomy and the character of the Prophet Muhammad. He follows traditions which are based on Tirmidhỉ's. ${ }^{52}$ Hākāanī

47 Uzun, "Hakani", 166-168.

48 Uzun, "Hakani", $166 \mathrm{ff}$.

49 Nagel, Allahs Liebling, 276-88.

50 Hākānī, Hilye, Istanbul 1264, 12, Hāḳānī, Hilye, Istanbul 13o8, 10.

$5^{1}$ Cf. the chapter on the vision of the Prophet, Tirmidhì, al-Shamā'il, 194-198.

$5^{2}$ On Hुākānī’s sources cf. Uzun, “Hakani”, 166ff. 
cites the attributes of the Prophet from the Arabic original, then translates and comments on each of them in nine to twenty-three Turkish verses. The following example comments on the attribute azhar al-lawn (bright of hue):53

Kāna rasūl Allāh ṣallā Allāhu 'alayhi wa-sallam azhar al-lawn İttifāḳ ètdi bu mánāda ümem ezherü l-levni idi fahr-i Ālem Yüzünüñ hāliṣ idi ağı ḳatı ruhları șāf idi șāfı șıfatı Reng-i rūyu gül idi yek-dil ile Kaplamışdır yüzünü nūr-ı sürūr gül gibi ḳırmızıya māil idi Muṣhafa-i husu idi ol-vech-i cemīl sūre-i nūr idi yā mațlaci-i nūr Gün yüzünden utanub āb-ı ḥayāt huațț-ı ruhsāarası nașș-ı tenzīl meskenin ètdi verā-i zulmāt Vech-i berrāḳının așḥāb-u șafā Gökde olmuşdu o ruy-i rengīn Aña vėrmişdi kemāl-i zīnet ḥumreti gālib idi dèr ḥattā şem'-i cem'-i harem-i illiyīn Garḳ-ālūd olıcaḳ ol sulțān Kātib-i çehre-küşā-yı fițret Gül-i pür-jāleye beñzerdi hemān

In Elias John Gibb's translation this passage reads as follows: ${ }^{54}$

[The messenger of God - God bless him and grant him salvation - bright of hue $]^{55}$

All the folk hereon agree

That the Pride of the world was bright of blee.

Full sheen was the radiance of his face

His cheeks were lustrous with lustre's grace

One of heart with the rose was his face's hue;

Like the rose, unto ruddiness is drew

Yclad his face in the light of delight,

'Twas the Chapter of Light or the dawn of light.

The scripture of beauty was that fair face;

The down on his cheeks was the verse of grace.

Shamed by his visage bright as day,

Life's fountain hid in the dark away.

Well may the comrades of joyance call:

'The sheen of his visage conquers all!'

Yon radiant face shone in the sky

The light of the harem-feast on high.

The Portrait-painter of Nature gave 
Thereto all beauty that man may have.

When the sweat upon that sultan stood

He was forsooth like the rose bedewed.

In the last twenty to thirty years of the seventeenth century - a few decades after Hākānī's death - a type of panel calligraphy developed in the Ottoman Empire, which is also named hilye or more precisely hilye-i şeriff. ${ }^{56}$ The central element of this type of calligraphic panel is a hadith about the physiognomy of the Prophet Muhammad. This hadith is written in a circle in the middle of the panel, in the corners four smaller circles with the names of the Rightly Guided Caliphs are situated, and at the top and the bottom two rectangles with verses from the Qurān. The basic element - the hadith in the middle of the panel obviously provides a link to Hākānī's poem, as well as to the common source a citation from the Shamāil-literature. But apart from the common source the two are at first sight independent.

\subsection{Beauty as a Common Link}

In the manuscripts of Hākānī's Hilye, an interrelation between topic, rhetoric and graphic design is self-evident. The topic is the physiognomy of the Prophet, which is to say, his beauty. The poet desires to translate the beauty of the hadith narratives into Turkish verses. The copyist and calligrapher pursue the same task when they write the verses down. Consequently, Hākāanì's text became popular among Ottoman calligraphers. The beauty of the script visualises the beauty of the Prophet. As mentioned above, we have to distinguish here between Hākāāīs poem Hilye, and hilye as a genre of panel-calligraphy. In fact, the calligrapher of the hilye panel omits the poet and refers directly to the hadith text.

The interrelation of theme, rhetoric and graphic elements in the manuscripts of Hākānī's poem can be classified into three types: 1. manuscripts and prints visualising theme and rhetoric by classical calligraphy, 2. manuscripts including illustrations, which belong to a broader repertoire of calligrams and pictures as visualisations of the Prophet (e.g. the seal of prophecy and the blossom of a rose), 3. manuscripts combining Ȟākānī's text with calligraphic figures, known from the hilye panels.

\subsection{Poetry and Calligraphy}

Hākānī's Hilye was a popular text for calligraphers. But only a small number of the extant manuscripts (e.g., in collections like the Süleymaniye Library or the

56 Cf. Elias, Aisha's Cushion, 270-82, Gruber, The Praiseworthy, 285-301, Taşkale and Gündüz, Hz. Muhammed'in Özellikleri, passim. 


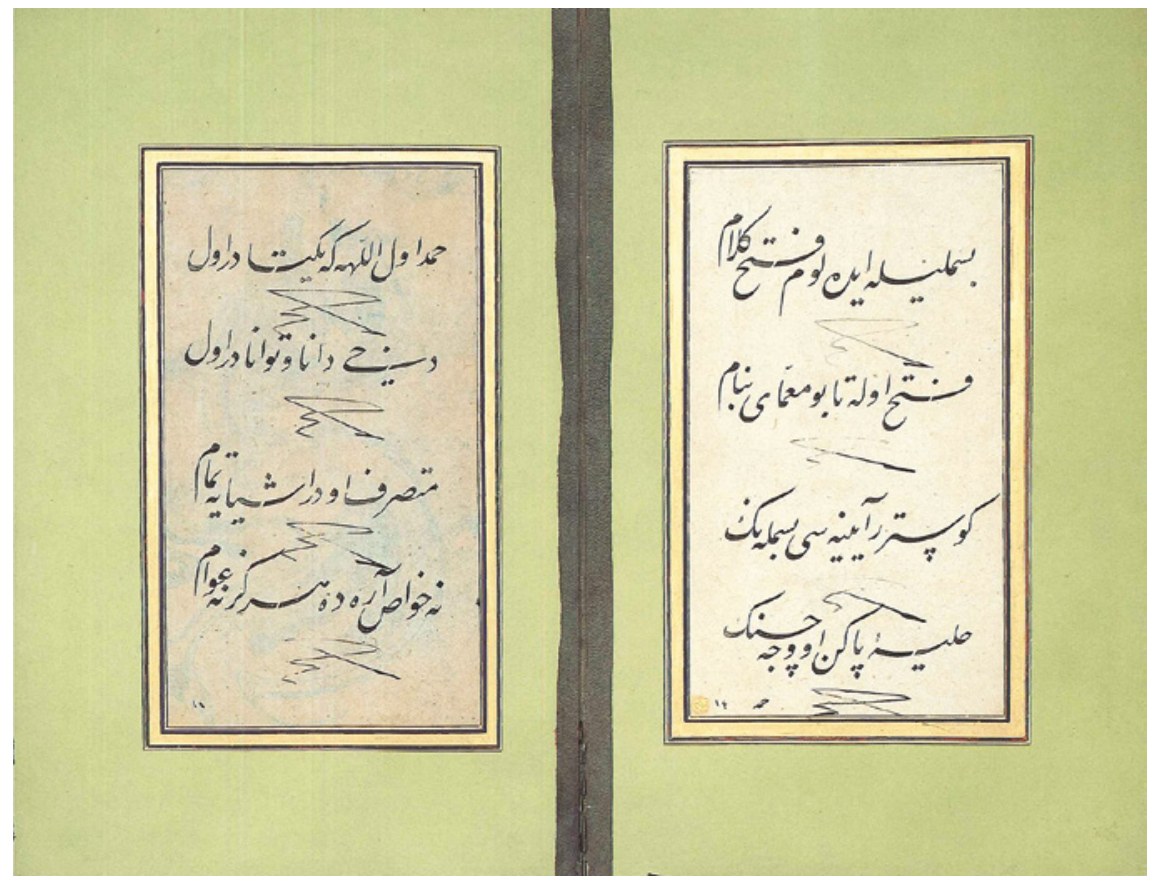

FIGURE 19.14 Hilye-i Hākâñü, selected verses as a panel (muraḳa ), by the calligrapher 'Arabzāde Meḥmed Sacdullāh, ssm (Sakıb Sabancı Müsesi), 120-0379

library of the Topkapı Palace) were written by professional calligraphers. These usually wrote selected verses on panels (levha) and in albums (murakka). In the latter, the topic - Muhammad's physiognomy - and the beauty of the language provided incentives to make the handwriting more elaborate). ${ }^{57}$ Exercising handicraft and artistry was linked to reflections on the beauty of the Prophet.

The first printed version of the Hilye-i Hākāni has to be seen in this context. In the 183 os and 1840 , a competition on the most beautiful movable types had developed among the official printing shops in Istanbul and Cairo. ${ }^{58}$ According to the colophon of the first Hilye print, it was the Ottoman Sultan who gave the order to the Imperial printing press in 1264/1848 to design new types for the ductus talik $k$. The two pages of the colophon explained the task in detail. Due to the large number of ligatures, this had to be an extraordinarily elaborate type font. ${ }^{59}$ The experts at the printing press designed it on the model of one

\section{Derman, Letters in Gold, $102 f$.}

$5^{8}$ Heinzelmann, "Ta'līk-Drucke", passim.

59 Hakān̄ī, Hilye, Istanbul 1264, 53ff., Birnbaum, "An Ottoman printing puzzle", passim, Derman, "Yazı San’atının", passim, Faulmann, Das Buch der Schrift, 108-111, Heinzelmann "Talīk-Drucke", 22 off. 


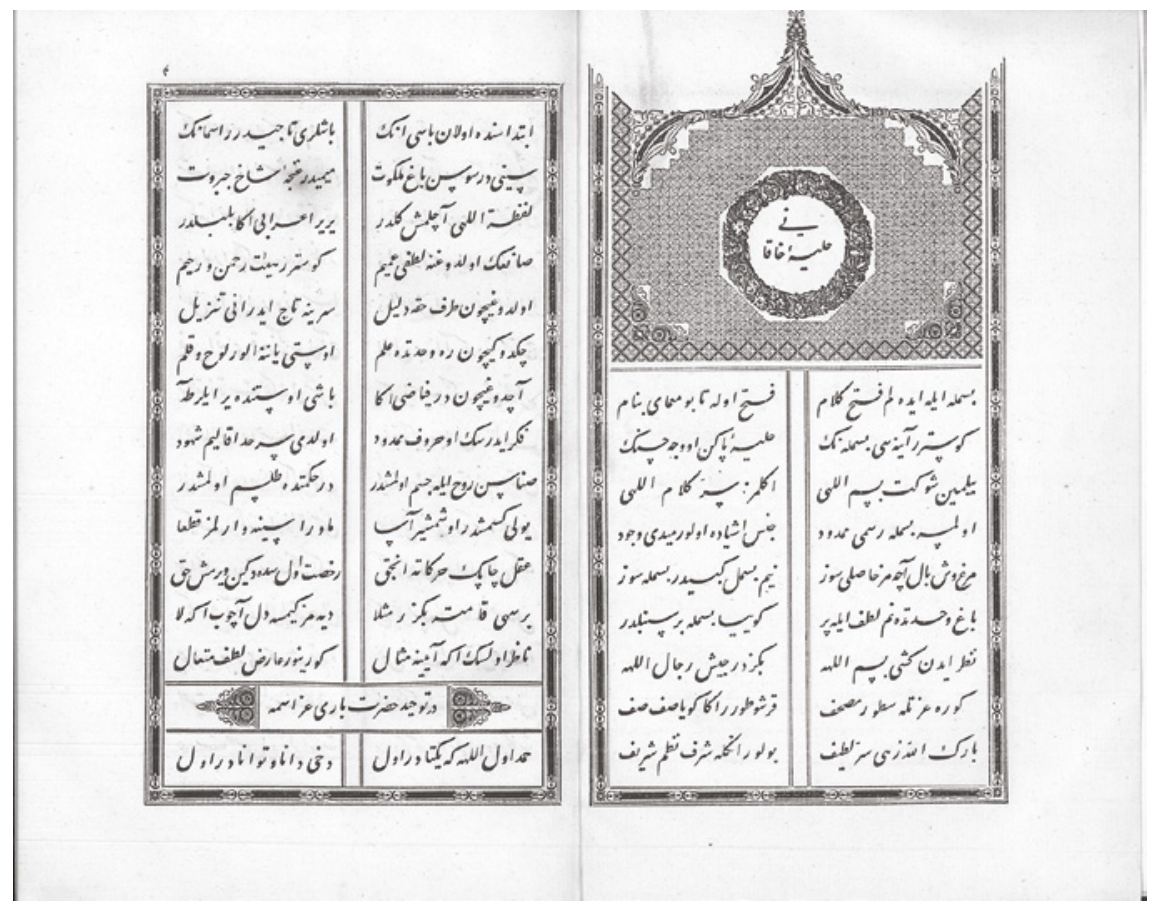

FIGURE 19.15 Hāḳānī, Hilye, printed Istanbul 1264/1848, introductory pages

of the most famous Iranian masters of the talitk ductus (in Persian nasta'lik), Mīr 'Imād al-Ḥasanī al-Kazvīnī (d. 1024/1615). ${ }^{60}$ When they had finished the task, they chose the Hilye-i Hakanni as the first text to be printed with the new font. The colophon of this first edition of the Hilye-i Hakāni reveals that it has to be seen in a long calligraphic tradition, where this text served to exercise the calligrapher's own handwriting - and offered during this process the chance to be inspired by the beauty of the Prophet. ${ }^{61}$

\subsection{Hilye Manuscripts with Illustrations}

Only a few manuscripts of Hāāānī’s hilye include illustrations. ${ }^{62}$ A luxury copy of the text is kept in the Hamidiye Library in Istanbul, as an endowment of Sultan 'Abdülhamīd I (r. 1774-89). sK Hamidiye 1075 is richly illuminated with floral patterns, using gold and different colours. It was copied 1130/1717 in an experienced, fluent talì $k$-ductus, and after the end of Hāākānī's text the miniature of a rose covers two thirds of the page. The signature under the

\footnotetext{
6o On Mīr 'Imād cf. Blair, Islamic calligraphy, $437 \mathrm{ff}$.

61 Cf. Gruber, The Praiseworthy, 3olff.

62 Cf. Gruber, The Praiseworthy, 297.
} 


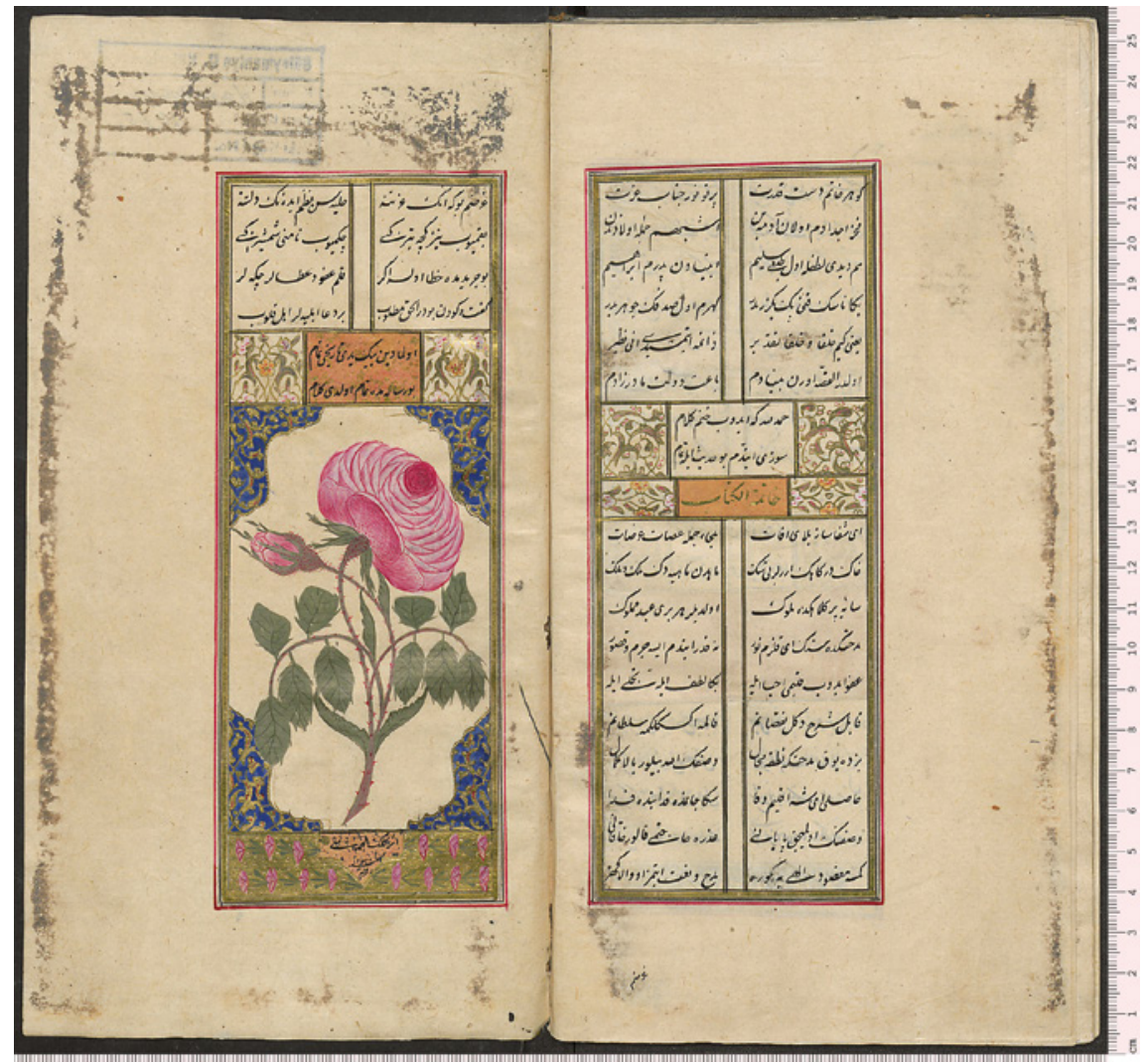

FIGURE 19.16 Hākān̄ī, Hilye, Rose as symbol of the Prophet. Hamidiye Library, endowment of Sultan 'Abdülhamīd I (r. 1774-89), sk Hamidiye 1075

rose - "work of Kelek Mehmed" (eser-i Kelek Mehmed) probably refers to the whole manuscript; the wording, however, is more that of an artisan than of a "copyist" - even if it is not possible to draw a strict line between the two according to this colophon/signature. The rose must be read as a reference to the above-cited verse "One of heart with the rose was his face's hue / Like the rose, unto ruddiness is drew" (Reng-i rūyu gül idi yek-dil ile/gül gibi kırmızıya $m \bar{a}$ il idi). Additionally, in the eighteenth century, it is a familiar image used to visualise the Prophet and can therefore also be regarded as an associatively chosen illustration of Huākānì's text. ${ }^{63}$

Hākāan̄is Hilye is a short text, which is frequently found as part of multipletext manuscripts. Some of these collections contain a rich diversity of religious texts; some are exclusively hilye collections. The volume sK Şehid Ali Paşa 2755

63 Gruber, "The Rose of the Prophet", 228. 


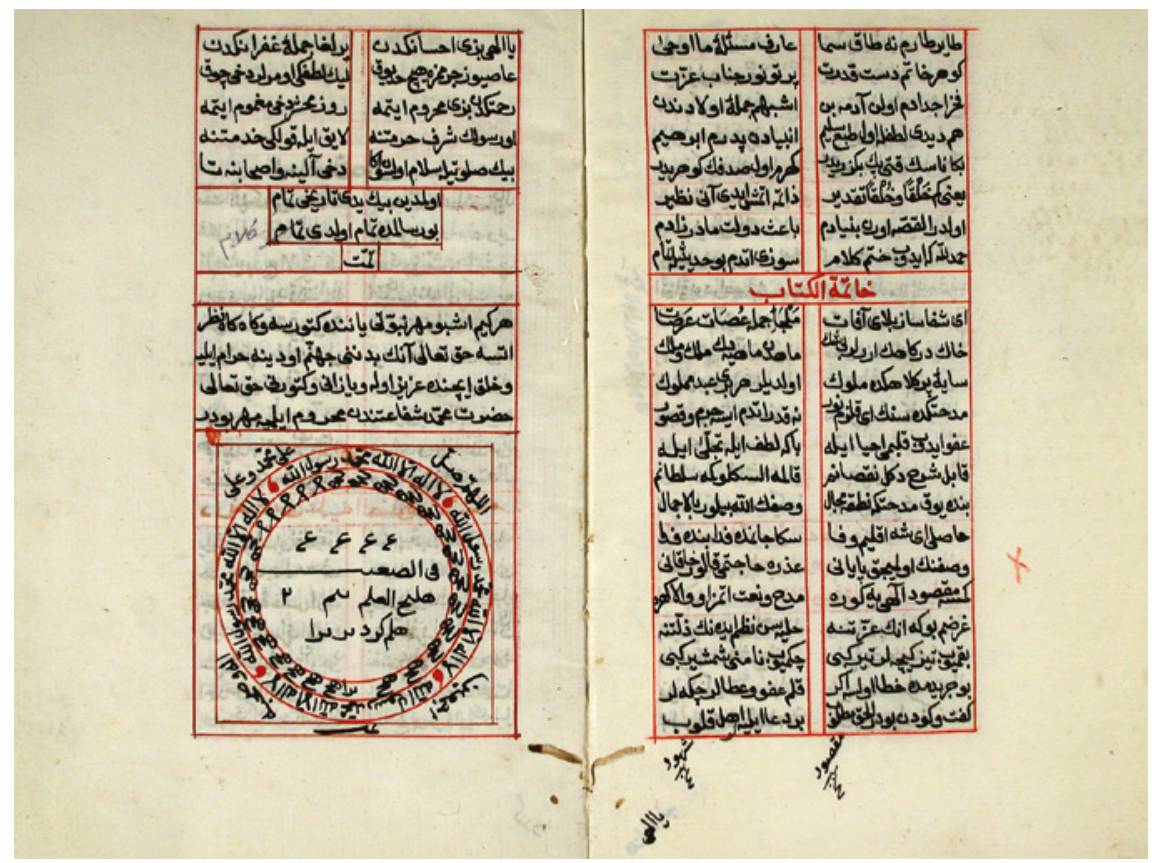

FIGURE 19.17 Hākāānī, Hịlye, "Seal of Prophethood" (mühr-i nubuvvet), sk Şehid Ali Paşa 2755, Istanbul, completed Tuesday, 18 ZA 1075/2 June 1665

belongs to the former category. ${ }^{64}$ It is part of the $v a k f$ library of the grand vizier Şehid Ali Paşa, (d. 1128/1716), and dated 1075/1665. ${ }^{65}$ The first three texts are Huākānìs Hilye, a poem on the hilye of the four Rightly Guided Caliphs (Hilye-i Çār Yār-i Güzìn) by Cevrī İbrāhīm Çelebi (d. 1065/1654), and a treatise in prose about the Prophet's hilye by a certain Şemseddin Sivasi - probably the famous Halvetiye shaykh of this name (d. 1006/1597). ${ }^{66}$ The remaining 26 texts of the volume, however, constitute a heterogeneous mixture of theological and Sufi treatises - by authors such as Birgivī or Kemālpaşazāde.

The copy of Haakannīs Hilye stands out due to a picture of the "seal of prophethood", which follows the colophon of the text and covers the rest of the page. ${ }^{67}$ (Figure 19.17 - Seal of Prophethood.) Above the picture, the seal's apotropaic effect is explained: "Everybody who bears this picture upon him/ her, and looks at it from time to time, will be saved from the fire of hell, and

64 SK Şehid Ali Paşa 2755, Tuesday, 18 ZA 1075/2 June 1665 (date on 34b).

65 Şemseddīn Sāmī, Sicill-i Osmanî, 1, 274.

66 Aksoy, "Şemseddîn Sivsâsî", 523-526, however, the hilye-treatise is not listed among his works.

67 Gruber, "Go Wherever You Wish", passim. 
he/she will be respected among the people, and God will not deny those who write it and bear it upon them Muhammad's intercession" (her kim işbu mühr-i nübüveti yanında getürse ve gāh gāh nazar ètse hakk ta ālā anuñ bedeninicehennem odına harām eyleye ve halk içinde 'azīz ola ve yazanı ve götüreni hakk ta'ālā hażret-i Muhammed şefāatından mahrūm eylemeye). Like the hilye sketches in the Muhammedīye manuscripts, this picture of the seal of prophethood is not an illustration of Hākānī's poem in a narrow sense. We rather have to understand it as just one more text in this multiple-text manuscript. Still, the connotation of the Prophet's hilye with the seal of prophethood and its apotropaic effect is striking. In this context, the caption - as well as the instruction for its use - picks up the idea that God saves those who see Muhammad's hilye in their dream - or the users of the apotropaic diagram of the seal - from the fire of Hell (bedenini cehennem odına haram eyleye vs. harrama Allāhu 'alayhi al-nār).

\subsection{Haḳānis Text and the Panel Calligraphy}

In contrast to the previous volume, sK Hüsrev 36 is a multiple-text-manuscript, which exclusively contains hilye-texts - two copies of the Hilye-i Häkānì, one copy with and one without vowel-signs, Cevrìs Hilye-i Çār Yär-i Güzīn (hillye of the four Rightly Guided Caliphs), Neşāț̣is Hilye-i Enbiy à and some unidentified, shorter hilye-texts in verse and prose. The whole volume is most likely copied by the same hand in an elegant nashi-ductus, and it is dated $1196 / 1781-$ 2, and kept in the vakf-collection of grand vizier Hüsrev Paşa (d. 1271/1855). The manuscript SK Hüsrev 36 is one of the rare manuscripts that documents a synthesis of the traditional layout of Ottoman poetry and the panel calligraphy of the hilye-i şerif. In addition to the poems and treatises in prose, the manuscript contains several circular shaped calligraphies of hadith-text about the physiognomy of the Prophet and the four Rightly Guided Caliphs in the original Arabic, clearly reminiscent of hilye-panels. I would not interpret these calligraphic diagrams as illustrations of one of the mentioned texts, but rather as texts in their own right.

sK Hüsrev 36 - as a hilye compilation - might therefore have functioned just like one of the murakka albums. On the one hand, the copying of the hilye texts is an act that brings about blessing. On the other hand, it is a deliberation upon the aesthetic aspects of the script - and, concomitantly, the aesthetic of the language and the beauty of the Prophet. In this regard, the two copies of the Hilye-i Hākannī - one with vowel signs and another without - are especially striking. Most of the vowel signs are - due to the vowel harmony - not very helpful for Ottoman-Turkish, except for those marking the Persian iżäfet or, in a few cases, those on the first syllable of a word. The vowel signs indicate 


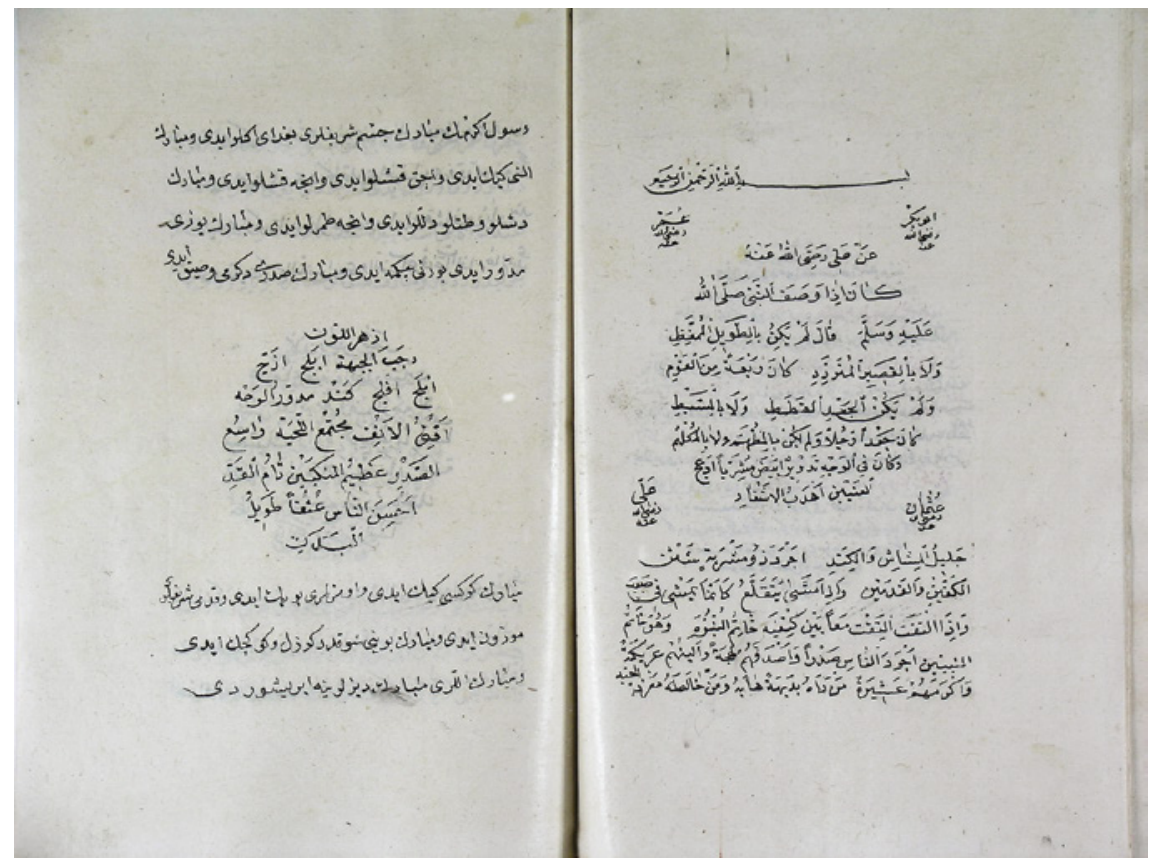

FIGURE 19.18 Hilye compilation, sk Istanbul, Hüsrev 36

rather the users' respect for certain texts - e.g., the Qurān. In case of the manuscript sk Hüsrev 36, they might also be the consequence of the calligrapher's deliberation on the vocalised text versus un-vocalised texts. In a further step, the calligrapher's process of aesthetic deliberation adapted the circular shaped diagrams of hadith texts from the hilye panels. In contrast to the illustrations in Yazıcıoğlı's Muhammedìye, neither illustrations like the blossom of the rose nor the elaborated logograms found their way into the printed editions.

\section{5}

\section{Conclusion}

The manuscripts and printed editions of the three poems - Süleymān Çelebi's Vesīlet en-Necāt, Yazıcıoğlı Muḥammed's Muhammedīye, and Huākānī’s Hilye differ considerably in their graphic characteristics. In contrast to the other two texts the copies of Süleymān Çelebi's poem are characterised by their frugal layout, which follows the classical two-column structure for poetry and represents basic techniques employed by Ottoman book culture to visualise the interrelation of content, rhetoric, and poetic form - especially the aesthetic 
aspects of handwritten calligraphy or markers like vowel signs. They indicate respect for the author, the text and the topic, and provided a visual marker of the authenticity for the copy.

The task of visualising the beauty of the Prophet through the beauty of calligraphy is quasi inherent in the topic of Hākānī's Hilye. Compared with Süleymān Çelebi's Vesīlet en-Necāt, copies of Hākāāīs text developed more elaborate patterns of calligraphy, and became a preferred text for calligraphers. In some examples of multiple-text manuscripts, it is also combined with the hilye logograms already known in Ottoman panel-calligraphy. Hāạānī's text is, in a few examples, also combined with other strategies to visualise the Prophet Muhammad - a painting of a rose, and a sketch of the "seal of prophethood". None of the latter was so influential that it was adapted in printed editions.

Yazıcıoğlı's Muhammedīye is distinguished by a broader variety of strategies to visualise the interrelation between graphic, rhetoric, and theme (the Prophet Muhammad). The "banner of praise" - as a visualisation of Muhammad - can already be found in the author's manuscript but it is also a constant in the text transmission through the centuries. Some of the graphic patterns developed later were restricted to a short period - like the fan calligraphy of the fakih tradition which had been developed to visualise the rhetorical peculiarities of the text.

An extraordinary graphic pattern - the visualisation of the narrative of Muhammad's biography through circles representing the Prophet and his contemporaries - is (virtually unprecendented) first documented in the early nineteenth century, but became remarkably successful in nineteenth- and early-twentieth-century prints. These schematic illustrations differ in the manuscripts and the printed versions concerning the scope of captions and labels, and the (schematic or naturalistic) depiction of the environment/ surroundings. This means that the interpretation of these pictures required a different scale of imaginative power from the readers. They reveal a figural impulse, which is subsumed in a schematic rendering.

\section{Bibliography}

\section{Primary Sources}

Ateş, A. Süleyman Çelebi - Vesîletü'n-Necât - Mevlid, Ankara, Türk Tarih Kurumu, 1954. Çelebioglu, Â. Muhammediye, Istanbul, Millî Eğitim Bakanlığı Yayınları, 2 vols., 1996. Pekolcay, N. Süleyman Çelebi - Mevlid, Istanbul, Dergah Yayınları, 1980. İsmā̄̄ll Ḥaḳḳ, Erzurumlu, Márifetnāme, ed. Yūsuf Żıyā, Istanbul, Mațbaaa-i Aḥmed Kāmil, 133 o. 
Lāmi'ī, M. b. 'O. Tercüme-i Nefahāt el-Üns, [i.e. Fütūḥ el-Mücāhidīn li-tervīh ḳulūb el-müşāhidin], Istanbul, s.n. 1289 .

Latîfî, [Tezkiret eş-Şu'arā'], Latîfîve Tezkiretü’ş-Şuarâ ve Tabsıratü’n-Nuzemâ, ed. Rızvan Canım, Ankara, Atatürk Kültür Merkezi Başkanlığı, 2000.

Süreyya, M. Sicill-i Osmanî: Osmanlı Ünlüleri, ed. Nuri Akbayar, 6 vols. Istanbul, Tarih Vakfi, 1996.

Muștafā 'Ālī, G. Künh el-Ahbār, 5 vols. Istanbul, Taḳvīmhāne-i ‘Āmire, 1277-1285.

Süleymān Çelebi, Mevlid-i Şerīf, [Muṣaḥhạ̣ Mevlid-i Şerīf], ed. Rıżā Beg, Istanbul, s.n. $1306 / 1888$.

Süleymān Çelebi, Muṣaḥhạ̣ Mevlid-i Şerīf, ed. Riżā Beg, Istanbul, Maḥmūd Beg Mațba'ası, 1327/19o9.

Süleymān Çelebi, Vesîletünn-Necât (Mevlid), Reisü'l-Hattātîn Ahmed Kâmil Akdik'in Hattıyla, ed. M. Akkuş and U. Derman, Ankara, Diyanet Bakanlığı Yayınları, 2008.

Ṭaşköprüzāde, 'I. al-D. A.l-Kh. A. b. M. al-Shaqā’iq an-nu'māniyya, ed. S. Furat, Istanbul, Edebiyat Fakültesi Basımevi, 1985.

Tirmidhī, A. 'I. M. b. S. al-. al-Shamā’il al-Muhammadiyya, ed. 'Izzat 'Ubayd ad-Du“ās, Beirut, Dār al-Ḥadīth, 1408/1988 (third ed.).

\section{Secondary Literature}

Aksoy, H. "Şemseddîn Sivâsî", in TDV İslâm Ansiklopedisi 38 (2010), 523-526.

Birnbaum, E. "An Ottoman Printing Puzzle: The Hilye-i Khāqānī of 1264/1848”, in C. E. Bosworth et al., eds. The Islamic World from Classical to Modern Times: Essays in Honor of Bernard Lewis, Princeton, Darwin Press, 1989, 433-49.

Blair, S. Islamic Calligraphy, Edinburgh, Edinburgh University Press, 2006.

Çağrıcı, M. “İbrâhim Hakkı Erzurumî”, TDV İslam Ansiklopedisi 21 (2000), 305-11.

Daub, F.-W. Formen und Funktionen des Layouts in arabischen Manuskripten anhand von Abschriften religiöser Texte, al-Bușīrīs Burda, al-Ğazūlīs Dalāil und die Šifä’ von Qā

Dehkhodā, 'A. A. et al. Loghatnāme-i Dehkhodā, 28 vol. Tehran, Dāneshgāh-i Tehrān, 1946-1975 (new ed. 1991).

Derman, U. "Hilye, Hat", in TDV İslâm Ansiklopedisi 18 (1998), 47-51.

Derman, U. Letters in Gold: Ottoman calligraphy from the Sakıb Sabancı collection, New York, Metropolitan Museum of Art, 1998.

Derman, U. "Yazı San'atının Eski Matbaacılığımıza Akisler", in Türk Kütüphaneciler Derneği (ed.), Bildiriler: Basım ve Yayıncılı̆ımızın 250. Yılı Bilimsel Toplantısı 10-11 Aralık 1979, Ankara, Türk Kütüphaneciler Derneği, s.a. 97-118.

Déroche, F. u.a. Islamic Codicology: An Introduction to the Study of Manuscripts in Arabic Script, London 1426 h./20o6.

Elias, J. J. Aisha's Cushion: Religious Art, Perception and Practice in Islam, Cambridge, MA, and London, Harvard University Press, 2012. 
Faulmann, C. Das Buch der Schrift: Enthaltend die Schriftzeichen und Alphabete aller Zeiten und aller Völker des Erdkreises, Wien, Kaiserlich-Königliche Hof- und Staatsdruckerei, 188 o.

Gacek, A. Arabic Manuscripts: A Vademecum for Readers, Handbook of Oriental Studies 1, 98, Leiden, Brill, 2009.

Gibb, E. J. W. A History of Ottoman Poetry, 6 vols. London, Luzac and Co., 19oo-19o9.

Gruber, C. "Between Logos (kalima) and Light (nür): Representations of the Prophet Muhammad in Islamic Painting", Muqarnas 26, 2009, 229-62.

Gruber, C. "A Pious Cure-All: The Ottoman Illustrated Prayer Manual in the Lilly Library", in C. Gruber, ed. Islamic Manuscript Tradition: Ten Centuries of Book Arts in Indiana University Collection, Bloomington, University of Indiana Press, 2010, 117-153.

Gruber, C. "Signs of the hour: Eschatological Imagery in Islamic Book Arts", Ars Orientalis 44 (2014), 40-6o.

Gruber, C. "The Rose of the Prophet: Floral Metaphors in Late Ottoman Devotional Art", in D. Roxburgh, ed. Envisioning Islamic Art and Architecture: Essays in Honor of Renata Holod, Leiden, Brill, 2014, 227-254.

Gruber, C. “Go wherever you wish, for verily you are well protected': Seal designs in late Ottoman

amulet scrolls and prayer books", in N. Timpano and J. Noble, eds., Visions of Enchantment: Occultism, Magic and Visual Culture, Lopen, Fulgur Press, 2019, 22-35.

Gruber, C. The Praiseworthy One: the Prophet Muhammad in Islamic Texts and Images, Bloomington, University of Indiana Press, 2019.

Heinzelmann, T. “Anfänge einer türkischen Philologie? Bursalı İsmācill Ḥaḳkı kopiert und kommentiert Yazıcıoghlı Meḥmeds Muhammediyye", in T. Heinzelmann and H. Sievert, eds., Buchkultur im Nahen Osten des 17. und 18. Jahrhunderts, Bern, Peter Lang, 2010, 99-150.

Heinzelmann, T. Populäre Religiöse Literatur und Buchkultur im Osmanischen Reich. Eine Studie zur Nutzung der Werke der Brüder Yazıcıoğlı, Würzburg, Ergon Verlag, 2015 .

Heinzelmann, Tobias, "Talīk-Drucke in Būlāḳ und Istanbul: Zum kalligraphischen Anspruch von Typendruck und Lithographie", in J. Zimmermann et al., eds., Osmanische Welten: Quellen und Fallstudien: Festschrift für Michael Ursinus, Bamberg, University of Bamberg Press, 2016, 209-241.

Karamustafa, A. T. "Cosmological diagrams", in J. B. Harley and D. Woodward, eds., The History of Cartography, Volume 2, Book 1, Cartography in the Traditional Islamic and South Asian Societie, Chicago, The University of Chicago Press, 1992, 71-89.

Maury, C. "Ottoman Representations of the two Sanctuaries: From Topographical Diagrams to Perspectival Views", in A. I. Al-Ghabban et al., eds., Roads of Arabia: 
Archaeology and History of the Kingdom of Saudi Arabia, Paris, Musée du Louvre, 2010, 547-59.

Nagel, T. Allahs Liebling: Ursprung und Erscheinungsform des Mohammedglaubens, München, R. Oldenbourg Verlag, 2008.

Sirriyeh, E. Dreams and Visions in The World of Islam: A History of Muslim Dreaming and Foreknowing, London, I. B. Tauris 2015.

Taşkale, F. and Gündüz, H. Hz. Muhammed'in Özellikleri: Hat Sanatında Hilye-i Şerife: Characteristics of the Prophet Muhammed in Calligraphic Art, Istanbul, Kültür Yayınları, 2006.

Topaloğlu, B. "Mârifetnâme”, TDV İslam Ansiklopedisi 28 (2003), $57 \mathrm{ff}$.

Uzun, M. "Hilye," TDV İslâm Ansiklopedisi 18 (1998), 44-47.

Uzun, M. "Hākânī Mehmed Bey," TDV İslâm Ansiklopedisi 15 (1997), 166-68.

Witkam, J. J. "The Battle of the Images. Mecca vs Medina in the Iconography of the Manuscripts of al-Jazūlī's Dalāil al-Khayrāt", in J. Pfeiffer and M. Kropp, eds. Theoretical Approaches to the Transmission and Edition of Oriental Manuscripts: Proceedings of a symposium held in Istanbul March 28-30, 2001, Würzburg, Ergon, 2007, 67-82.

Witkam, J. J. Vroomheid an Activisme in een Islamitisch Gebedenboek: De geschiedenis van de Dalā’il al-Khayrāt van al-Ğazūlī, Leiden, Legatum Warnerianum, Universiteitsbibliotheek, 2002.

Ziriklī, K. al-. Al-A'̄ām: Qāmūs tarājim li-ashhar ar-rijāl wan-nisā’ min al-Arab wa-l-musta'ribin wa-l-mustashriqin, 13 vols, Beirut, s.n. 1969-197o.

Türkiye Diyanet Vakfı İslam Ansiklopedisi, 44 Bd. Istanbul 1988-2013. 